Boise State University

ScholarWorks

Geosciences Faculty Publications and

Presentations

$11-26-2012$

\title{
Variability of Pennsylvanian-Permian Carbonate Associations and Implications for NW Pangea Palaeogeography, East-Central British Columbia, Canada
}

\author{
K. D. Zubin-Stathopoulos \\ University of Calgary \\ B. Beauchamp \\ University of Calgary \\ V. I. Davydov \\ Boise State University \\ C. M. Henderson \\ University of Calgary
}




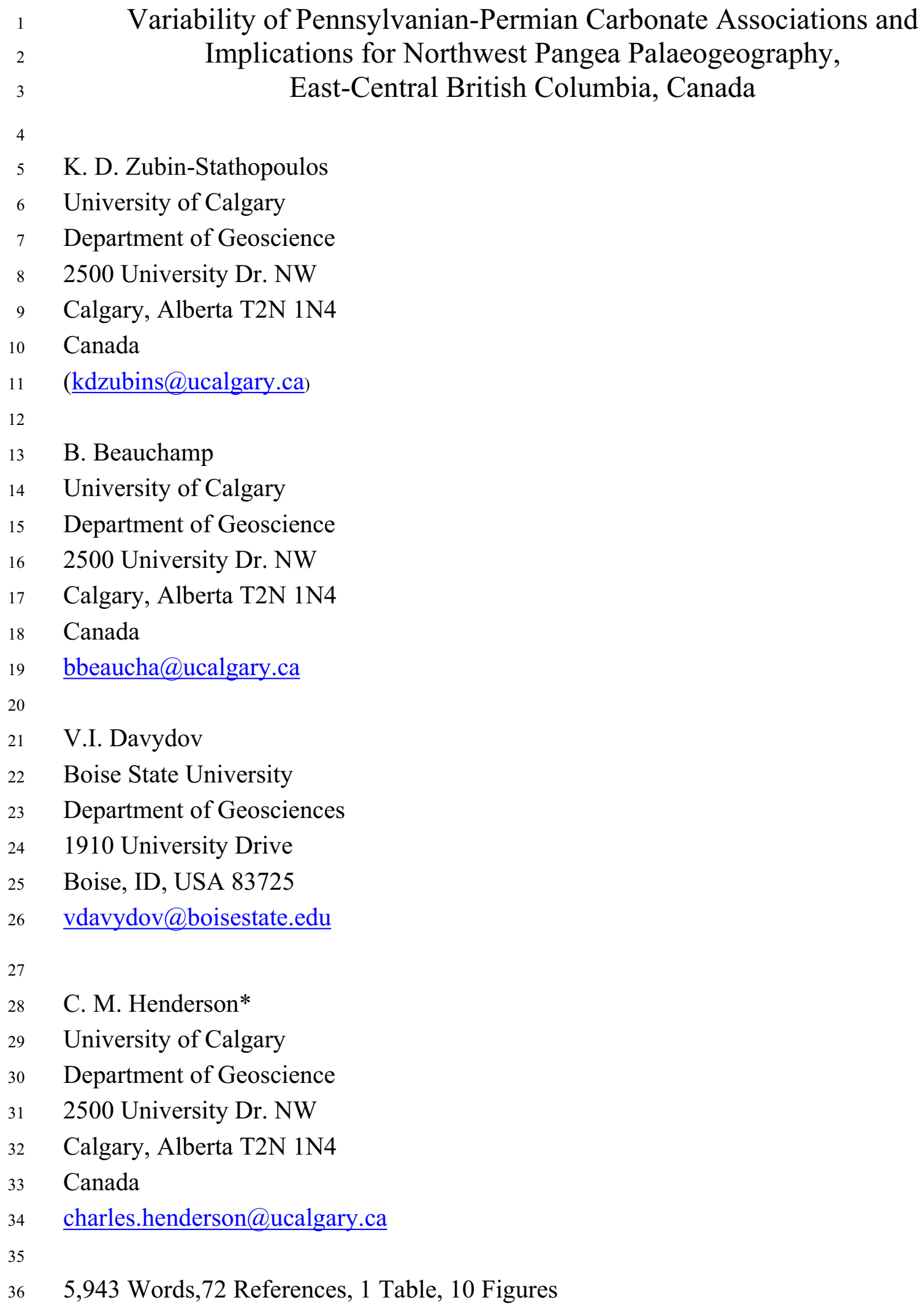

$5 \quad$ K. D. Zubin-Stathopoulos

6 University of Calgary

7 Department of Geoscience

82500 University Dr. NW

9 Calgary, Alberta T2N 1N4

10 Canada

11 (kdzubins@ucalgary.ca)

13 B. Beauchamp

14 University of Calgary

15 Department of Geoscience

162500 University Dr. NW

17 Calgary, Alberta T2N 1N4

18 Canada

19 bbeaucha@ucalgary.ca

21 V.I. Davydov

22 Boise State University

23 Department of Geosciences

241910 University Drive

25 Boise, ID, USA 83725

$26 \quad$ vdavydov@boisestate.edu

C. M. Henderson*

University of Calgary

Department of Geoscience

2500 University Dr. NW

Calgary, Alberta T2N 1N4

Canada

charles.henderson@ucalgary.ca

5,943 Words, 72 References, 1 Table, 10 Figures

20

27

37 


\footnotetext{
39 Abstract

40 Different stages of Pennsylvanian-Permian carbonate sedimentation in east-central

41 British Columbia record a complex history of changing environments influenced by

42 evolving palaeogeography and climate. Newly recognized tectonically controlled features

43 affected the distribution and variability of carbonate associations, providing new

44 interpretations for this portion of the west coast of Pangea. Both a heterozoan (cool-

45 water) and photozoan (warm-water) association were identified on either side of a

46 palaeogeographic high here informally termed "Tipinahokan Peninsula". Cool water

47 carbonates were located outboard, or to the west of this high, an area influenced by

48 upwelling waters. Inboard of this high, a warm, protected sea developed, here termed

49 "Kisosowin Sea". This configuration and palaeolatitude is similar to that of Baja

50 California, Mexico and the Sea of Cortéz, providing a good modern analog for these

51 deposits where warm water carbonates grow at latitudes otherwise dominated by cool

52 water deposits. The warm sea provided a place for a photozoan association to develop

53 during the Permian when the low latitude NW coast of Pangea was dominated by cool

54 water carbonates.

55

Key Words: Palaeoclimate, carbonate associations, western Pangea, ocean circulation,

57 Pennsylvanian, Permian, upwelling, biostratigraphy. 
Pennsylvanian-Permian strata in east-central British Columbia, western Canada, consist of carbonate rocks with a small siliciclastic component and are predominantly skeletal wackestone and packstone (Bamber \& Macqueen 1979). Localized occurrences of grainstone and boundstone that record warm water carbonate deposition also occur in the eastern and southern portion of the area. This occurrence is unusual because it is present in an area that is otherwise dominated by cool water limestone, dolostone and phosphatic siltstone. This aspect of western Pangean sedimentation has not been addressed in previous studies (Bamber \& Macqueen 1979; McGugan \& RapsonMcGugan 1976). This paper explains the anomalous occurrence of these warm water carbonates by the emergence of a Late Pennsylvanian topographic high that separated and protected a warm inland sea to the east from a significantly cooler open ocean affected by upwelling to the west.

Pennsylvanian and Lower Permian carbonate reefs and mounds typical of tropical to sub-tropical settings have been well documented in the Western United States and the Canadian Arctic (Davies et al. 1989; Beauchamp \& Desrochers 1997; Morin et al. 1994; Wahlman 2002). The Pennsylvanian-Permian basins of the western U.S. were located near the palaeo-equator where warm shallow water prevailed (Blakey 2008). At higher latitudes, tropical to sub-tropical seas also developed, such as in the Sverdrup Basin of the Canadian Arctic, an area that was bathed by warm waters originating from the Tethyan Ocean prior to the closure of the Uralian seaway (Reid et al. 2007). The reefbuilding organism Palaeoaplysina, as well as colonial rugose corals and calcareous green algae have been documented in British Columbia (Bamber \& Macqueen 1979). These 
81 fossils form a photozoan biotic association, which is typical of shallow warm water tropical-like conditions (James 1997).

This paper documents the facies variability of Pennsylvanian-Lower Permian carbonates in east-central British Columbia focusing on differences in biotic associations and other sedimentological attributes. Such differences are often attributed to climate change over time (e.g. Beauchamp 1994). However, this study shows that distinctive warm and cool water shallow water shelf deposits accumulated at the same time while remaining unaffected by the major climatic shift that occurred across the AsselianSakmarian boundary associated with the thawing of Gondwana glaciers. We here present an alternative interpretation whereby the significant difference in carbonate associations is explained by the existence of a protected sea that allowed warm water carbonates to grow in the western portion of the Peace River Basin. The name Kisosowin Sea (Kisosowin means "warm" in Cree) is here informally ascribed to this palaeogeographic feature. The Kisosowin Sea was protected by a Late Pennsylvanian-Early Permian topographic high, herein termed the Tipinahokan Peninsula (Tipinahokan means "shelter from the cold" in Cree), that acted as a barrier sheltering the area of warm water sedimentation to the east from an area cooled by upwelling to the west.

\section{Geological Setting}

\section{Study Area and Methods}

Pennsylvanian-Permian strata from the westernmost portion of the Western Canada Sedimentary Basin (WCSB) crop out in a NW-SE trending belt in eastern British 
103 Columbia and western Alberta. This study focuses on outcrops in map sheets 93I, P, O and 94B where the succession is relatively well exposed in a series of Laramide thrust sheets of the Rocky Mountains (Fig. 1). The eight measured sections include Peck Creek, Mountain Creek, Watson Peak, Mount Palsson, Mount Crum, Fellers Creek, Mount Cornock and Ganoid Ridge. In addition to new outcrop data collected in 2009 and 2010, our study incorporates published field descriptions of Bamber \& Macqueen (1979) and McGugan \& Rapson-McGugan (1976). Mountain Creek and Fellers Creek, which are the most complete sections we measured, are described in greater detail. Exploration wells are also used for correlation to the eastern Peace River Basin where the biostratigraphy and sedimentology is better understood.

In total, 116 conodont samples and 203 thin sections were processed from the eight measured sections. This paper relies on biostratigraphic data and age interpretations outlined in Zubin-Stathopoulos (2011). Facies analysis was conducted using thin sections, cut slabs, outcrop photographs and field notes. Standard procedures for petrographic analysis were used for identifying and imaging carbonate constituents. Gamma readings were taken at Fellers Creek, Mountain Creek, Ganoid Ridge, Watson Peak, Mount Crum and Mount Palsson using a hand held scintillometer. The carbonate classification scheme of Dunham (1962) is used as well as modifiers for carbonate associations including the terms "photozoan" and "heterozoan" to qualify the environmental controls (temperature, nutrients, etc.) of carbonate constituents (James 1997). In addition, assemblages specific to late Palaeozoic biota (bryonoderm, bryonoderm-extended) were used (Beauchamp 1994). 


\section{Stratigraphic Setting}

Compared to the Mississippian succession, which consistently ranges in the hundreds of metres from the US-Canada border to the Northwest Territory, the PennsylvanianPermian succession of Alberta and eastern British Columbian is relatively thin, quite variable in composition and recorded a complex stratigraphic-sedimentological history at a time of ongoing tectonic activity in the WCSB. In east-central British Columbia, Pennsylvanian-Permian rocks are dominated by shallow water carbonate and chert with varying siliciclastic proportions that generally increase upward (Bamber \& Macqueen, 1979). This succession comprises eight relatively thin unconformity-bounded low order sequences that can be correlated from the Rocky Mountains in the west to the subsurface areas in the east (Fig. 2) (Bamber \& Macqueen 1979; McGugan \& Rapson-McGugan 1976; Zubin-Stathopoulos 2011). In the study area, these sequences are represented by the Kindle, Belcourt, Fantasque and Mowitch formations (Bamber \& Macqueen 1979). Pennsylvanian strata in the area are equivalent to the Ksituan Formation of Henderson et al. (1994). The Upper Pennsylvanian-Lower Permian sequences in east-central BC are equivalent to part of the Belloy Formation in the subsurface to the east (Dunn 2003; Naqvi 1972) while the Middle Permian units are equivalent to the upper Belloy Formation (Dunn 2003). While they differ lithologically, these units are equivalent in age to formations in southeast British Columbia and southwest Alberta (MacRae \& McGugan 1977; McGugan \& Rapson 1962 1963).

The studied succession is part of three low-order sequences of Moscovian, Kasimovian-Gzhelian and Asselian-Sakmarian respectively (Figs. 2 and 3). The three sequences are contained within the Belcourt Formation. The sequence boundaries are 
sharp, erosive and unconformable surfaces associated with intraformational conglomerates of probable near-shore origin (Fig. 4). The Pennsylvanian portion of the Belcourt Formation (Moscovian) is correlative to the Ksituan Formation. The Belcourt Formation is a unit of fossiliferous carbonate that recorded moderately deep water to shallow shelf or ramp cyclic sedimentation (Bamber \& Macqueen 1979). In the study area, the formation varies in thickness (Fig. 3), ranging from zero at Mt. Cornock up to $127 \mathrm{~m}$ at Mountain Creek (Fig. 3). Southern and eastern outcrops display typical Belcourt facies, i.e. grainstone (ooid and skeletal), boundstone and lesser amounts of skeletal wackestone and packstone, a suite of facies that is best preserved at Fellers Creek (Fig. 4). The western section displays a different composition, which consists dominantly of lime-mudstone, skeletal wackestone and packstone, and minor amounts of skeletal grainstone. This succession is best exemplified at Mountain Creek (Fig. 5). We are of the opinion that a new formation could be erected to reflect this basic and mappable lithological difference within the Belcourt Formation. For the purpose of this paper, however, we will refer to the Fellers Creek Assemblage (FCA) (eastern and southern area) and the Mountain Creek Assemblage facies (MCA) (western area) of the Belcourt Formation as shown in Figure 2.

\section{Peace River Basin and Tectonic Highs}

The deposits described in this study are located in the western part of the Peace River Basin. The Peace River Basin is a down-warped and down-faulted portion of the interior cratonic platform (Henderson et al. 2002) of North America that became an area of 
171 carbonate and clastic deposition during the Pennsylvanian-Permian interval (Henderson

172

173

et al. 1994). The Peace River Basin is a complex tectono-stratigraphic element at the convergence of multiple tectonic interactions and was the locus of both differential subsidence and uplift that occurred at varying rates and time in different areas. The location of the Peace River Basin was in part determined by tectonically-controlled palaeogeographic elements such as the Beatton High and Sukunka Uplift (Henderson et al. 2002). In addition, it is now apparent that the Peace River Basin and adjacent Ishbel Trough to the west (Richards et al. 1993) are divided into discrete sub-basins (Henderson et al. 2002).

In the study area, a prominent tectonic high, the NW-SE axis of which is intersected at Mt. Cornock (Fig. 3), separated two distinct depositional areas to the west and east. While the Belcourt Formation is absent on the crest of the high, such as Mt. Cornock (Fig. 3), it thickens markedly to the east and west of the high. The high also constitutes the physical boundary between the area dominated by the Mountain Creek facies assemblage of the Belcourt Formation to the west and the Fellers Creek facies assemblage to the east (Fig. 3). Evidence of recurrent tectonic activity along the high is shown by several horizons with intraformational conglomerates, some of which contain clasts derived from the immediately underlying succession (Fig. 4).

\section{Palaeolatitudinal Setting}

Various palaeogeographic reconstructions of Pangea places the study area in eastern British Columbia between 20 and $25^{\circ} \mathrm{N}$ during the Moscovian-Kasimovian and 25 to $30^{\circ}$ 
193 N during the Asselian-Kungurian (Blakey 2008; Golonka \& Ford 2000; Vai 2003). These estimates are based on published reconstructions that rely on palaeomagnetism, palaeobiogeography, best global fit of tectonic plates and comparisons with modern latitudinal gradients and corresponding facies (Golonka \& Ford 2000). Contemporaneous deposits in the southwestern United States (Texas to Utah) are interpreted to be equatorial, ranging from 0 to $10^{\circ} \mathrm{N}$ and having migrated $10^{\circ}$ northward during the Kasimovian to Kungurian interval (Tabor et al. 2008). The Sverdrup Basin of the Canadian Arctic is interpreted as being located at about $25-30^{\circ} \mathrm{N}$ in the latest Pennsylvanian (Gzhelian) to Early Permian (Asselian-Sakmarian), based on extensive warm-water photozoan carbonates, and to have migrated to approximately $40^{\circ} \mathrm{N}$ by the Middle Permian as suggested by dominance of cool- to cold-water heterozoan carbonates (Beauchamp 1994; Bensing et al. 2008). This significant oceanic cooling has been associated with the closure of Uralian seaway during the Artinskian that prevented warm Tethyan-derived waters from reaching NW Pangea (Reid et al. 2007). Based on these considerations, east-central British Columbia may have been at a slightly lower latitude than suggested by some global reconstructions, possibly ranging from 15 to $20^{\circ} \mathrm{N}$ during the Early Permian, which would coincide with the modern distribution of warm water carbonates (Halfar et al. 2004a) and place the area well within the range of Coriolisdriven Ekman transport and upwelling along the western margin of Pangea. 
The Pennsylvanian-Early Permian interval was characterized by relatively high sea level with cyclic influence from glacial eustasy (Golonka \& Ford 2000) at a time of widespread glaciation in Gondwana (Wanless \& Shepard, 1936). Cyclothems are well known and described from the western United States where the climate was wetequatorial (Heckel 1986; Wanless \& Shepard 1936). These cyclothems classically consist of deep marine shale, followed by regressive marine limestone and capped by shallow marine or terrestrial (coal) deposits (Heckel 2008). Arid cyclothems are less well known, but are shown to be present in higher latitude deposits of western and northern Canada (Ford et al. 2009; Heckel 2002; Moore 2002; Morin et al. 1994). Some of these cyclothems commonly contain evaporites as their capping unit (ex. sabkha-type dolostone and sulfate evaporites). Aeolian-sourced silt is pervasive throughout these deposits (Heckel 2002).

Arid conditions persisted throughout the Pennsylvanian in the Western United States, Canada and Russia (Francis 1994) and continued during the Permian resulting in widespread evaporitic and desert environments. These conditions also led to abundant aeolian silt deposition within Pennsylvanian to Middle Permian marine carbonates (Francis 1994; Soreghan et al. 2008). The end of widespread Gondwana glaciation roughly coincides with the Asselian-Sakmarian boundary, above which high amplitudehigh frequency sequences or cycles are not as well developed as in older PennsylvanianEarly Permian sediments (Beauchamp \& Henderson 1994). Sea level was at a near minimum toward the end of the Kungurian (Golonka \& Ford 2000; Soreghan et al. 2008). During the Middle Permian, arid conditions coupled with cool water deposition prevailed 
236 all along the northwestern margin of Pangea at a time of global warming (Beauchamp \& Baud 2002; Clapham 2010).

As observed around the world, the Pennsylvanian-Lower Permian succession of eastcentral British Columbia displays a series of high-order cycles as recorded by fluctuations in carbonate facies representing environments ranging from outer shelf (or ramp) to shoreline (see descriptions below). This is shown by fluctuations from lime mudstone to packstone to grainstone in the Asselian succession at Fellers Creek (Fig. 4), and from lime mudstone to wackstone and packstone in the Moscovian to Asselian succession at Mountain Creek (Fig. 5). Cycles average 5-10 $\mathrm{m}$ in thickness, which is similar to contemporaneous cyclothems in the mid-continent (Heckel 2002) and in the Arctic (Morin et al. 1994). However, the number of observed cycles varies greatly from section to section and is considerably smaller than the number of cycles observed elsewhere. This reflects the incomplete nature and highly variable preservation of the PennsylvanianPermian succession in east-central British Columbia, which attests for erosion and/or non-deposition at time of active differential tectonic uplift and subsidence. The Sakmarian succession at Fellers Creek displays only 2-3 shelf cycles, which may also reflect an incomplete stratigraphic record. However, only a few shelf cycles are observed in the Sakmarian succession of the Sverdrup Basin, at a time of widespread global transgression contemporaneous with the thawing of Gondwana glaciers. 
The Moscovian to Sakmarian succession of east-central British Columbia comprises 12 carbonate microfacies (MF), the content and interpretation of which is summarized in Table 1. The microfacies are illustrated in Figs. 6 and 7. The interpreted depositional environments range from relatively deep (below storm wave base) low energy outer shelf or ramp (MF-09), to storm-influenced middle ramp (MF-03, MF-08), to high energy shallow inner ramp/shoreface (above fair weather wave base) (MF-01 to MF-03; MF-07, MF-10, MF-12). Most facies represent open marine sedimentation, except for MF-05 (protected inner ramp), and MF-04 that represents potentially inter- to supra-tidal, backramp deposition.

Both photozoan and heterozoan biotic associations were observed. Photozoan biota includes telltale indicators of shallow, warm-water tropical-like conditions such as dasycladacean algae, colonial rugose corals, Palaeoaplysina and ooids. Palaeoaplysina is an organism with unknown biological affinity that may belong to the class hydrozoa (Davies \& Nassichuk, 1973), though it has also been interpreted to be closely related to calcareous algae (Watkins \& Wilson, 1989). It is usually found in shallow water, high productivity environments where photosynthesizing organisms are common (Davies \& Nassichuk, 1973). It is considered to be part of the photozoan association and formed bioherms in a moderate to low energy environment on the inner to outer ramp.

Heterozoan biota are far less diversified and dominated by sponge spicules, bryozoan, echinoderm and brachiopods, a typical Late Palaeozoic cool-water assemblage also known as Bryonoderm (Beauchamp 1994). Cool-water conditions reflect deeper depositional settings (MF-08 and MF-09) or shallow -water deposition in an area bathed by cool to cold waters (MF-10 to MF-12). In the latter case, it is not the biota that 
280 indicates shallow water deposition, but different lines of evidence such as the dominance of grainstones or presence of cross-beddings or ripples. One of the most distinctive aspects of the studied succession is the dominance of photozoan carbonates in the eastern and southern sections, as seen at Fellers Creek (Fig. 4) (Fellers Creek facies assemblage).

In contrast, heterozoan carbonates dominate the western sections as exemplified at Mountain Creek (Fig. 5) (Mountain Creek facies assemblage).

Various combinations of the twelve facies occur recurrently in the study area and can be found at various stratigraphic levels of the Belcourt Formation. The recurrence of facies sets attest for shifts in relative sea level in response to ongoing high-frequency glacio-eustatic fluctuations. While the entire spectrum of facies is never present within a single vertical cycle, facies variations do suggest bathymetric shifts in the order of 30 to $50 \mathrm{~m}$ on average for each cycle as environments shifted from offshore, distal outer shelf sedimentation below storm wave base to high energy nearshore, shoreline and even supra-tidal sedimentation and erosion.

While it is impossible to correlate individual cycles from section to section due to the extreme lateral and vertical variations in the number of cycles, we can analyze the spectrum of microfacies through the prism of the three low-order sequences in the area, the Moscovian, Kasimovian-Gzhelian, and the Asselian-Sakmarian sequences. Each of these sequences, which represent the grouping of an undetermined number of high-order cycles, has its own set of depositional characteristics as described below (Fig. 8).

\section{Moscovian}


The Moscovian portion of the Belcourt Formation consists of bioturbated silty mudstone (MF-08), bryozoan-brachiopod wackestone-packstone (MF-09) and fine grained packstone/grainstone (MF-12) (Fig. 4). These three facies alternate in a cyclic fashion, shallowing up from MF-09 to MF-08 and capped by MF-12. The capping facies progressively gets muddier upwards, and the mudstone portion of the cycle becomes thicker indicating overall deepening upward succession for these cycles. The Moscovian portion of the Fellers Creek section consists of conglomerate-containing chert and carbonate clasts (Fig. 4). The bryozoans and brachiopods require normal marine salinity and circulation in order to develop indicating that these sediments represent deposition in an open marine environment (Fig. 8A). The Moscovian found elsewhere in the Peace River Basin is mostly assigned to the Ksituan Formation, which is predominantly composed of finely crystalline dolostone and is interpreted as shallow tidal flat deposits in sabkhas and lagoons (Dunn 2003; Wamsteeker 2007).

Conodont taxa recovered from the Moscovian interval include Adetognathus lautus, Diplognathodus edentulus, Neognathodus bothrops and Idiognathodus expanses (ZubinStathopoulos 2011). This sequence starts at the conglomerate at the base of the Belcourt Formation at Fellers Creek and Mountain Creek section (Figs. 4 and 5). The sequence displays extreme thickness variations ranging from zero at some outcrops (Mount Palsson, Mount Cornock, etc.) to $164 \mathrm{~m}$ in the subsurface in the Peace River Basin. The Moscovian portion of the Mountain Creek section coarsens upward (shallowing upward) with up to 6 shallowing-upward cycles (Fig. 4).

Thicknesses are controlled in part by palaeogeographic features that caused both erosion and non-deposition of this sequence (Zubin-Stathopoulos 2011). Localized 
325 palaeogeographic highs were present, which resulted in the deposition of Moscovian aged conglomerates containing Mississippian clasts at Fellers Creek. Palaeogeographic highs that were uplifted from the Late Pennsylvanian through Early Permian resulted in the erosion of this sequence, but the preservation of Moscovian aged conodonts (Neognathodus bothrops) within carbonate clasts found in a lag indicates that Moscovian rocks were more pervasive than what is seen at many outcrops (Zubin-Stathopoulos 2011).

This sequence is characterized by overall open marine conditions (Fig. 8A) with no indication of a restricted or protected marine environment, except in back ramp environments suggested by facies of the Ksituan Formation. The alternation of dominantly lime mudstone beds with periodic wackestone and packstone beds containing chaotically organized brachiopod and bryozoan fragments indicates an overall deep, low energy environment below storm wave base with shallowing upward cycles that end in storm influenced beds at the tops. Mountain Creek is located in the westernmost thrust sheet of all of the outcrops studied. The facies and location within this thrust sheet imply that these are the most distal sediments. The carbonate association indicates deposition on a relatively deep to shallow cool water carbonate ramp (Fig. 8A).

\section{Kasimovian-Gzhelian}

Rocks representing these two Late Pennsylvanian stages are not prominent in the study area, but are present at Mountain Creek and West Sukunka. The KasimovianGzhelian portion of the Belcourt Formation consists of bioturbated silty mudstone (MF- 
04) and bryozoan-brachiopod wackestone-packstone (MF-09). The carbonate association indicates cool, moderately deep water. The facies and location within the westernmost thrust sheet imply that these are the most distal sediments deposited on the outer ramp. The correlation of these stages is based on the occurrence of Adetognathus lautus and New Genus A sp. (Kasimovian) (Zubin-Stathopoulos 2011). This succession is up to $70 \mathrm{~m}$ in the outcrop belt, though it is usually not present. Our limited data set for this sequence prevents us from suggesting a sequence-specific interpretation. The range of depositional environments was likely similar to that of the Moscovian (Fig. 8A).

\section{Asselian-Sakmarian}

The Asselian-Sakmarian succession is bounded by prominent unconformities and is therefore believed to constitute a single low-order sequence. However, an additional erosion surface associated with conglomerates and potentially representing an unconformity occurs at Fellers Creek and is viewed as representing the AsselianSakmarian boundary (Fig. 4). It also likely represents the boundary between two higherorder sequences within the lower order Asselian-Sakmarian sequence. Because of this, we here describe the Asselian part of this sequence first, and then the Sakmarian part below. This makes sense considering that the Asselian was still a time of Gondwana glaciations while glacial thaw and retreat occurred during the Sakmarian.

The Asselian portion of the Belcourt Formation consists of ooid-foraminifer grainstone (MF-01), Palaeoaplysina packstone/boundstone (MF-06), algal-bioclastic grainstone (MF-02), rugose coral wackestone-packstone (MF-05), microbial 
mudstone/dolostone (MF-04) and bryozoan-echinoderm packstone-grainstone (MF-03).

These light- and warm temperature-dependent organisms constitute a Photozoan Association (James 1997). The Asselian portion of the Mountain Creek section consists largely of MF-02 (bryozoan-brachiopod wackestone-packstone) with some alternation with MF-01 (silty bioturbated mudstone). Some levels contain brachiopod hash in a limemud matrix and represent brachiopod banks.

Conodont taxa in this sequence include Adetognathus n.sp. B, Streptognathodus verus, and Streptognathodus fusus (Zubin-Stathopoulos 2011). The Asselian part of the sequence ranges from 0 to $20 \mathrm{~m}$ in the outcrop belt. It is not recognized in the eastern Peace River Basin, possibly due to low global sea level resulting in non-deposition or poor preservation (Golonka \& Ford 2000). Distinct shallowing-upward cycles are present at both the Fellers Creek (Fig. 4) and Mountain Creek sections (Fig. 5). Active tectonism during this interval created a palaeogeographic high between the western sections and the eastern sections (Fig. 3). This high formed during the Asselian just to the west of Fellers Creek. Deposits at the Fellers Creek section represent a photozoan carbonate ramp that fostered the growth of temperature dependent organisms such as Palaeoaplysina and fusulinaceans as well as abiotic constituents such as ooids (Fig. 8B). Deposits at the Mountain Creek section represent a heterozoan carbonate ramp that contained only heterozoan elements including brachiopod and bryozoan (Fig. 8B). The Sakmarian facies (Fig. 8C) found at Fellers Creek include Palaeoaplysina boundstone (MF-06), colonial rugose coral boundstone (MF-07) algal-bioclastic grainstone (MF-02), and echinoderm-brachiopod packstone-grainstone (MF-03). These facies are part of the photozoan carbonate association (James 1997; Reid et al. 2007). Facies found at 
392 Mountain Creek include bryozoan-brachiopod wackestone-packstone (MF-08), cross bedded silty mudstone-wackestone (MF-11), and hummocky cross-stratified mudstone (MF-10). These belong to a heterozoan carbonate association (James 1997; Reid et al. 2007) of the bryonoderm variety (Beauchamp \& Desrohers 1997).

Biostratigraphically significant fossils in this sequence include the conodont Sweetognathus binodosus (Zubin-Stathopoulos 2011) and the coral Protowentzelella kunthi (E.W. Bamber, pers. comm. 2010). Two closely spaced samples with fusulinaceans at 37.5 and 39.5 were recovered in the Fellers Creek section. The fusulinaceans are quite abundant in the samples, but their taxonomy is rather poor. Three species are identified in both samples (Fig. 9): Schubertella ex gr. kingi Dunbar \& Skinner, Pseudofusulina attenuata Skinner \& Wilde and Ps. acuta Skinner \& Wilde. The first species is an opportunistic schubertellid that is widely distributed globally and occurs in latest Gzhelian through entire Lower Permian (Davydov, 2011). The other two species were originally described from the McCloud Limestone in Shasta Lake area (Skinner \& Wilde, 1965). Pseudofusulina attenuata has also been found in Nevada in a stratigraphically very narrow horizon (Stevens et al., 1979; Davydov et al., 1997). In Nevada the horizon with Pseudofusulina attenuata yields the conodonts Mesogondolella aff. striata Chernykh near the bottom and Sweetognathus aff. merrilli Kozur near the top (Wang 1993; V. Chernykh 2008 pers. comm.) suggesting late Asselian to early Sakmarian age for this unit (Chernykh, 2005). The Sakmarian is not recognized in the subsurface of the eastern Peace River Basin. Only a $15 \mathrm{~m}$ thick interval occurs at Fellers Creek (Fig. 4), which is correlated to other Sakmarian occurrences at Kinuseo Creek and 
414 Meosin Mountain. Sakmarian aged rocks are also found at Mountain Creek. This part of the sequence developed at a time of global sea level rise and active tectonism.

The palaeogeographic high that was present during the Asselian persisted through the Sakmarian (Figs. 8B-C) and probably into the Artinskian and Kungurian. This high continued to separate photozoan carbonates to the east from heterozoan carbonates to the west throughout the Sakmarian. Sediments on the flanks of this high were deposited on a carbonate ramp with bioherms. Sediment more distal to the flanks were deposited on a ramp that more closely resembles a siliciclastic ramp, where carbonate producing organisms did not build mounds or wave resistant structures (Figs. 8B-C).

\section{Western Pangean Climate and Oceanic Currents}

The occurrence of warm-water photozoan associations in east-central British Columbia could be attributed to a climatic warming event. However, it has been suggested that a southward cool boundary current existed along the entire west coast of Pangea creating increasing cool water conditions starting in the Early Permian with most pronounced effects in the Middle Permian (Beauchamp \& Baud 2002; Clapham 2010). Northern and northwestern Pangea was cooling and decoupled from a broader global warming trend (Clapham 2010). The Middle Permian basin of west Texas was experiencing warmer water temperatures, while just north in the Phosphoria Sea, cool water deposits prevailed (Clapham 2010). The Guadalupian of east central British Columbia also records a similar climatic story to that of the Sverdrup Basin and the 
basins of the western United States. Cool water deposits are recorded along the entire western coast of Pangea, dominantly consisting of spiculite and chert indicative of this cooling episode (Beauchamp \& Baud, 2002; Clapham, 2010).

Carbonate reefs that are typical of photozoan associations are well documented in the western United States within tectonically controlled sub-basins such as the Wood River Basin (Wahlman 2002). There is an abundance of cool water deposits in British Columbia including the spiculitic and phosphatic siltstone of the Johnston Canyon Formation in southeastern British Columbia and southwestern Alberta located within the southern portion of the Ishbel Trough (MacRae \& McGugan 1977). This also indicates that this cool boundary current had a control on the fauna of the Early Permian in eastcentral British Columbia. In addition, the palaeolatitude indicates that at least seasonal upwelling influenced these deposits, creating an environment conducive only to a heterozoan carbonate production. Despite the existence of a cool boundary current that became progressively more pronounced through the Permian, patch reefs and mounds typical of the photozoan or warm water carbonate associations were able to develop in this isolated area on the northwestern coast of Pangea.

\section{Warm to cool carbonate deposition and palaeogeography}

Warm water carbonate associations (photozoan) are defined as a group of benthic carbonate particles including light dependent organisms and/or non-skeletal particles (ooids) plus or minus non-light dependent components (James 1997). Other examples of constituents found within the photozoan association include warm water corals, green 
458 algae and fusulinaceans. The Fellers Creek facies assemblage of the Belcourt Formation predominantly consists of skeletal packstone and grainstone containing many of these constituents. It occurs in an isolated area within the outcrop belt in the central and southern portion of the study area. The Belcourt Formation can generally be characterized as deposited in a warm shallow sea where carbonate producing organisms were protected from cool upwelling ocean currents that would have prevented photozoan carbonates from growing. These organisms would have also required clear, oligotrophic waters in order to develop (Halfar et al. 2004a).

Several outcrops within the study area have no Pennsylvanian to Early Permian deposits. In contrast, the Fantasque Formation (Middle Permian) is present nearly everywhere, though it is missing at Watson Peak. This series of outcrops are interpreted as the location of a tectonic high that was active from the Late Pennsylvanian through the Early Permian, located to the west of outcrops that represent deposition in the Kisosowin Sea (Fig. 10). This high developed during the Kasimovian C6 tectonic episode (Fig. 2) and may have extended into the Early Permian P1 event, described from Nevada (Snyder et al. 2002; Trexler et al. 2004) and outlined in detail in Zubin-Stathopoulos (2011) for east-central British Columbia (Fig. 10). Microcodium found in shallow water deposits within the Asselian and Sakmarian sequences indicates that this high may have been host to the development of soil and vegetation (Kosir 2004). It was centred approximately at $20^{\circ} \mathrm{N}$ palaeolatitude.

The fusulinacean assemblage with Pseudofusulina attenuata and Ps. acuta can be attributed to the McCloud province (Ross, 1995), where the fusulinaceans and coral faunas at certain horizons include significant Tethyan warm-water elements (Ross, 1995; 
481 Fedorowsky et al., 2007). The occurrence of this exotic for North American province

482 assemblage in central Nevada and in east-central British Columbia $1800 \mathrm{~km}$ to the north suggests a warming episode along the North American margin during early Sakmarian time as well as a linkage with Klamath/Quesnel arc rocks (Fig. 10) to the west. Belasky et al. (2002) suggested, based on faunal similarities that the Quesnel and Klamath terranes must have been 2000-3000 km away from their latitudinal equivalents on the NA craton during the Early Permian. Models developed by Nelson et al. (2006) suggest that the Slide Mountain Ocean (and therefore also the Havallah Basin) was the locus for back-arc sea floor spreading and would have been distant from the NA craton. Henderson et al. (in press) highlighted the importance of timing and suggested the development of a peripheral bulge that closed the Kisosowin Sea in the early Artinskian points to terrane interaction with the NA craton. This would suggest a narrower Slide Mountain Ocean and Havallah Basin, which seems to be supported by the fusulinacean assemblage. It is apparent that the climatic warming suggested by the occurrence of these McCloud tethyan warm-water elements in east-central British Columbia is insufficient by itself to account for this association given the prevailing cool-water currents affecting the margin at these palaeolatitudes. The Kisosowin Sea clearly represents a protected embayment that was able to foster these warm water organisms during the Early Permian (Fig. 10).

Cool-water carbonate associations, or heterozoan associations, are defined as a group of benthic carbonate particles produced by organisms that are light-independent plus or minus red calcareous algae (James 1997). Common carbonate producing organisms found within this association include brachiopods, bryozoans, mollusks, echinoderms and some foraminifers. The Mountain Creek facies assemblage of the Belcourt Formation 
504 predominantly consists of wackestone and packstone with minor grainstone that are part of the Heterozoan association with no indication of photozoan elements. This assemblage occurs at outcrops in the westernmost thrust sheet in the study area located west of outcrops that represent the Tipinahokan Peninsula.

\section{Baja California: Modern Anologue for the Tipinahokan Peninsula}

Baja California is a southward extending peninsula on the west coast of Mexico that protects a gulf, or sea (Sea of Cortéz/Gulf of California) with the opening to this embayment to the south. The peninsula is located between 22 and $32^{\circ} \mathrm{N}$ latitude and experiences seasonal upwelling along the Pacific coast (Walsh et al. 1977). Upwelling directly affects food chain dynamics, with marked changes when upwelling is slow or even at times when the current reverses and downwelling occurs along this coast (Walsh et al. 1977). Upwelling is at its maximum from February to June. The Sea of Cortéz is considered to be "a mostly isolated, distinct body of water" with different biological populations on the Pacific coast of the Baja peninsula (Lluch-Belda et al. 2003). Despite this, the California Current reaches the mouth of the Sea of Cortéz, allowing some interchange between the Pacific Ocean and the opening of the gulf (Lluch-Belda et al. 2003). This brings not only cool water, but nutrients to the sediments at the mouth of the Sea of Cortéz.

The most northern occurrence of reef-forming hermatypic corals occur within the southern portion of the Sea of Cortéz near an area called La Paz, which is at $24^{\circ} \mathrm{N}$ latitude (Halfar et al. 2004a). This area is characterized as a warm-temperate carbonate 
526 realm with a mixed heterozoan-photozoan association (Halfar et al. 2004b). Mean sea

527 surface temperature is at $24^{\circ} \mathrm{C}$, allowing the growth of photozoan carbonates (James 1997). Farther north in the Sea of Cortéz, the majority of carbonate producing organisms consists of mollusks and rodoliths, with occasional, and often older, reworked coral indicating a heterozoan carbonate association (Halfar et al. 2004b). This occurrence of reef-forming corals is due to the protected oceanographic conditions that allow for warm water and oligotrophic to mesotrophic conditions necessary for photozoan carbonate production (Halfar et al. 2004b).

The configuration of the Sea of Cortéz with protected photozoan carbonates on the inside of the peninsula is a good analogue for the late Palaeozoic of east-central British Columbia. It not only occurs at comparable latitude on the west coast of a continent, but modern climate is representative of an interglacial period, similar to that of the many interglacials during the Asselian-Sakmarian. This presence of a palaeogeographic high with warm-water carbonates to the east and cool water carbonates to the west within latitudes that experiences at least seasonal upwelling resembles the geographic configuration and biotic distribution of Baja California (see inset in Fig. 2). Photozoan carbonates within the Sea of Cortéz are characterized as warm-temperate because of the lack of green algae and extensive reef-forming carbonates (Halfar et al. 2004b).

Photozoan carbonates within the Kisosowin Sea can be characterized as subtropical because of the presence of calcareous green algae, hermatypic coral and ooids (James et al. 1999). This difference in the carbonate organisms between the Sea of Cortéz and the Kisosowin Sea despite the similarity in latitude and geography may be due to several factors including warmer global temperatures during the Permian and basin configuration 
549 that would promote more oligotrophic conditions allowing photozoan carbonates to 550 develop.

551

Conclusions

The emergence of the Tipinahokan Peninsula during the Late Pennsylvanian created a protected sea that emulated the conditions found in tropical to subtropical PennsylvanianPermian basins of the western United States such as the Midland, Orogrande, Paradox and Wood River basins as well as the tethyan McCloud limestone of the Klamath arc. The warm-water carbonates of the Kisosowin Sea were situated in a palaeolatitude that should have experienced cool water sedimentation from upwelling, indicating important linkages between climate, oceanic currents and tectonically controlled basins. In particular, our study demonstrates the existence of a Moscovian open ocean embayment with little restriction except in back-ramp lagoon and sabkha environments. This was followed by the emergence of the Tipinahokan Peninsula, which began during the Late Pennsylvanian C6 event and later climaxed during the Early Permian P1 event. The Tipinahokan Peninsula was fully emergent by the Asselian through the Sakmarian allowing a photozoan carbonate ramp to develop in the protected Kisosowin Sea to the east. A cool-water heterozoan carbonate ramp influenced by nutrient-rich upwelling waters existed to the west of the Tipinahokan Peninsula.

This study thus demonstrates the presence of a cool upwelling system along the northwest margin of Pangea at a time when substantially warmer water carbonate sedimentation occurred well over a $1000 \mathrm{kms}$ to the north in the Sverdrup Basin (Arctic 
571 Canada) and to the south in Nevada. Finally, our study shows that the major global

572 climatic shift across the Asselian-Sakmarian boundary, which is associated with the

573 thawing of Gondwana ice sheets, did not solely affect carbonate sedimentation in our

574 study area.

576 Acknowledgements: Geoscience BC and Talisman Energy Inc. provided financial

577 support that made this research in a remote area possible. This project was also

578 financially supported by Natural Sciences and Engineering Research Council of Canada

579 (NSERC) Discovery grants held by Charles M. Henderson and Benoit Beauchamp. 


\section{References}

Aretz, M., Herbig, H.G., Somerville, I.D., \& Cûzar, P., 2010. Rugose coral biostromes in the late Viséan (Mississippian) of NW Ireland: Bioevents on an extensive carbonate platform. Palaeogeography, Palaeoclimatology, Palaeoecology, 292, 488-506.

Bamber, E.W., \& Macqueen, R.W., 1979. Upper Carboniferous and Permian stratigraphy of the Monkman Pass and Southern Pine Pass areas, northeastern British Columbia. Bulletin Geological Survey of Canada, 301, 27.

Beauchamp, B., 1994. Permian climatic cooling in the Canadian Arctic. Special Paper Geological Society of America, 288, 229-246.

Beauchamp, B., \& Baud, A., 2002. Growth and demise of Permian biogenic chert along northwest Pangea: evidence for end-Permian collapse of thermohaline circulation. Palaeogeography, Palaeoclimatology, Palaeoecology, 184, 37-63.

Beauchamp, B., \& Desrochers, A., 1997. Permian warm- to very cold-water carbonates and cherts in Northwest Pangea. Special Publication, Society for Sedimentary Geology, 56, 327-347.

Beauchamp, B., \& Henderson, C.M., 1994. The Lower Permian Raanes, Great Bear Cape and Trappers Cove formations, Sverdrup Basin, Canadian Arctic: stratigraphy and conodont zonation. Bulletin of Canadian Petroleum Geology, 42, 562-597.

Belasky, P., Stevens, C.H., \& Hanger, R.A., 2002. Early Permian location of western North American terranes based on brachiopod, fusulinid and coral biogeography. Palaeogeography, Palaeoclimatology, Palaeoecology, 179, 245-266.

Bensing, J.P., James, N.P., \& Beauchamp, B., 2008. Carbonate Deposition During a Time of Mid-Latitude Ocean Cooling: Early Permian Subtropical Sedimentation in the Sverdrup Basin, Arctic Canada. Journal of Sedimentary Research, 78, 2-15.

Blakey, R.C., 2008. Pennsylvanian-Jurassic Sedimentary Basins of the Colorado Plateau and Southern Rocky Mountains, in Andrew, D.M., (ed) Sedimentary Basins of the World, 5, 245-296.

Boyd, R., 2010. Transgressive wave-dominated coasts, in James, N.P., \& Dalrymple, R.W., (eds) Facies Models 4, CSPG, 265-294.

Chernykh, V.V., 2005. Zonal methods in biostratigraphy: zonal conodont scale of the Lower Permian in the Urals. (In Russian) Institute of Geology and Geochemistry, Uralian Branch of the Russian Academy of Sciences Ekaterinburg, 217.

Clapham, M.E., 2010. Faunal evidence for a cool boundary current and decoupled regional climate cooling in the Permian of western Laurentia. Palaeogeography, Palaeoclimatology, Palaeoecology, 298, 3-4.

Coates, A.G., \& Jackson, J.B.C., 1987. Clonal Growth, Algal Symbiosis, and Reef Formation by Corals. Paleobiology, 13, 363-378. 
Davies, G.R., \& Nassichuk, W.W., 1973. The Hydrozoan? Palaeoaplysina from the Upper Paleozoic of Ellesmere Island, Arctic Canada. Journal of Paleontology, 47, 251-265.

Davies, G.R., Richards, B.C., Beauchamp, B., \& Nassichuk, W.W., 1989. Carboniferous and Permian Reefs in Canada and Adjacent Areas. Canadian Society of Petroleum Geologists, 13, 565-574.

Davydov, V.I., 2011. Taxonomy, nomenclature and evolution of the early schubertellids (Fusulinida, Foraminifera). Acta Palaeontologica Polonica, 56 (1), 181-194.

Davydov, V.I., Snyder, W.S., Spinosa, C., Ross, C.A., Ross, J.R.P., \& Brenckle, P.L., 1997. Permian foraminiferal biostratigraphy and sequence stratigraphy of Nevada. Special Publications - Cushman Foundation for Foraminiferal Research, 36, 3134.

Dunham, R.J., 1962. Classification of carbonate rocks according to depositional texture. Memoir American Association of Petroleum Geologists, 1, 108-121.

Dunn, L., 2003. Sequence biostratigraphy and depositional environmental modeling of the Pennsylvanian-Permian Belloy Formation, northwest Alberta and northeast British Columbia. Ph.D. thesis, University of Calgary.

Embry, A.F., III, \& Klovan, J.E., 1971. A late Devonian reef tract on northeastern Banks Island, N.W.T. Bulletin of Canadian Petroleum Geology, 19, 730-781.

Federowski, J., Bamber, E.W., \& Stevens, C.H., 2007. Lower Permian colonial rugose corals, western and northwestern Pangaea; taxonomy and distribution. National Research Council of Canada, Ottawa, Ont., Canada.

Ford, C.M., Henderson, C.M., Hubbard, S.M., Soreghan, G.S., Hathaway, K., Soreghan, M., \& Davydov, V.I., 2009. Geologic Record of Arid Climate Cyclothems in the Upper Pennsylvanian and Lower Permian Tobermory and Kananaskis Formations of Fortress Mountain Ridge Section. CSPG CSEG CWLS Convention: Calgary, Alberta, 771-774.

Francis, J.E., 1994. Paleoclimates of Pangea; geological evidence: Memoir, Canadian Society of Petroleum Geologists, 17, 265-274.

Frey, R.W., 1990. Trace fossils and hummocky cross-stratification, Upper Cretaceous of Utah. Palaios, 5, 203-218.

Frisia, S., 1994. Mechanisms of Complete Dolomitization in a Carbonate Shelf: Comparison between the Norian Dolomia Principale (Italy) and the Holocene of Abu Dhabi Sabkha, In Purser, B., Tucker, M., \& Zenger, D., (eds) Dolomites, Blackwell Publishing Ltd., 55-74.

Golonka, J., \& Ford, D., 2000. Pangean (Late Carboniferous-Middle Jurassic) paleoenvironment and lithofacies. Palaeogeography, Palaeoclimatology, Palaeoecology, 161, 1-34. 
Halfar, J., Godinez-Orta, L., Mutti, M., Valdez-Holguin, J.E., \& Borges, J.M., 2004a. Nutrient and temperature controls on modern carbonate production: An example from the Gulf of California, Mexico. Geology, 32, 213-216.

Halfar, J., Ingle, J.C., \& Godinez-Orta, L., 2004b. Modern non-tropical mixed carbonatesiliciclastic sediments and environments of the southwestern Gulf of California, Mexico. Sedimentary Geology, 165, 93-115.

Heckel, P.H., 1986. Sea-level curve for Pennsylvanian eustatic marine transgressiveregressive depositional cycles along Midcontinent outcrop belt, North America. Geology, 14, 330-334.

—, 2002. Overview of Pennsylvanian cyclothems in Midcontinent North America and brief summary of those elsewhere in the world. Memoir, Canadian Society of Petroleum Geologists, 19, 79-98.

—, 2008. Pennsylvanian cyclothems in Midcontinent North America as far-field effects of waxing and waning of Gondwana ice sheets. Geological Society of America, Special Papers, 441, 275-289.

Henderson, C.M., Dunn, L., Fossenier, K., \& Moore, D., 2002. Sequence biostratigraphy and paleogeography of the Pennsylvanian-Permian Belloy Formation and outcrop equivalents in Western Canada: Memoir, Canadian Society of Petroleum Geologists, 19, 934-947.

Henderson, C.M., Richards, B.C., Barclay, J.E., Mossop, G.D., \& Shetsen, I., 1994. Permian strata of the Western Canada Sedimentary Basin, In Mossop, G.D., \& Shetsen, I., (eds) Geologic Atlas of the Western Canada Sedimentary Basin, Geological Survey of Canada, 251-258.

Henderson, C.M., Zubin-Stathopoulos, K.D., \& Dean, G.J., in press. Chronostratigraphic and tectonostratigraphic summary of the Late Paleozoic and Early Triassic succession in east-central British Columbia. In Geoscience BC summary of activities 2011, Geoscience BC, Report 2012-1.

Hubert, J.F., 1978. Paleosol caliche in the New Haven Arkose, Newark Group, Connecticut. Palaeogeography, Palaeoclimatology, Palaeoecology, 24, 151-168.

James, N.P., 1997. The cool-water carbonate depositional realm. Special Publication, Society for Sedimentary Geology, 56, 1-20.

James, N.P., Collins, L.B., Bone, Y., \& Hallock, P., 1999. Subtropical carbonates in a temperate realm; modern sediments on the Southwest Australian shelf. Journal of Sedimentary Research, 69, 1297-1321.

James, N.P., Frank, T.D., \& Fielding, C.R., 2009. Carbonate sedimentation in a Permian high-latitude, subpolar depositional realm; Queensland, Australia. Journal of Sedimentary Research, 79, 125-143. 
Jones, B., 2010. Warm-water neritic carbonates, In James, N.P., \& Dalrymple, R.W., (eds) Facies Models 4, CSPG, 341-369.

Kepper, J.C., 1966. Primary dolostone patterns in the Utah-Nevada Middle Cambrian. Journal of Sedimentary Research, 36, 548-562.

Klappa, C.F., 1978. Biolithogenesis of Microcodium: elucidation. Sedimentology, 25, 489-522.

Kosir, A., 2004, Microcodium Revisited: Root Calcification Products of Terrestrial Plants on Carbonate-Rich Substrates. Journal of Sedimentary Research, 74, 845-857.

Lluch-Belda, D., Lluch-Cota, D.B., \& Lluch-Cota, S.E., 2003. Baja California's Biological Transition Zones: Refuges for the California Sardine. Journal of Oceanography, 59, 503-513.

MacRae, J., \& McGugan, A., 1977. Permian stratigraphy and sedimentologysouthwestern Alberta and southeastern British Columbia. Bulletin of Canadian Petroleum Geology, 25, 752-766.

Mastandrea, A., Perri, E., Russo, F., Spadafora, A., \& Tucker, M., 2006. Microbial primary dolomite from a Norian carbonate platform: northern Calabria, southern Italy. Sedimentology, 53, 465-480.

McGugan, A., \& Rapson, J.E., 1962. Permo-Carboniferous stratigraphy, Crowsnest area, Alberta and British Columbia. Journal of the Alberta Society of Petroleum Geologists, 10, 352-368.

—, 1963. Permo-Carboniferous stratigraphy between Banff and Jasper, Alberta. Bulletin of Canadian Petroleum Geology, 11, 150-160.

McGugan, A., \& Rapson-McGugan, J.E., 1976. Permian and Carboniferous stratigraphy, Wapiti Lake area, northeastern British Columbia. Bulletin of Canadian Petroleum Geology, 24, 193-210.

Moore, D., 2002. The Stratigraphy of the Pennsylvanian and Lower Permian Tobermory, Kananaskis and Johnston Canyon Formations of the Front Ranges of the Southern Canadian Rocky Mountains, Alberta and British Columbia. Masters thesis, University of Calgary.

Morin, J., Desrochers, A., \& Beauchamp, B., 1994. Facies analysis of Lower Permian platform carbonates, Sverdrup Basin, Canadian Arctic Archipelago. Facies, 31, $105-130$.

Naqvi, I.H., 1972. The Belloy Formation (Permian), Peace River area, northern Alberta and northeastern British Columbia. Bulletin of Canadian Petroleum Geology, 20, 58-88.

Nelson, J.L., Colpron, M., Piercey, S.J., Dusel-Bacon, C., Murphy, D.C., \& Roots, C.F., 2006. Paleozoic tectonic and metallogenic evolution of the pericratonic terranes in 
Yukon, northern British Columbia and eastern Alaska. Geological Association of Canada Special Paper, 45, p. 323-360.

Rapson-McGugan, J.E., 1970. The diagenesis and depositional environment of the Permian Ranger Canyon and Mowitch formations, Ishbel Group, from the southern Canadian Rocky Mountains. Sedimentology, 15, 363-417.

Reid, C.M., James, N.P., Beauchamp, B., \& Kyser, T.K., 2007. Faunal turnover and changing oceanography: Late Palaeozoic warm-to-cool water carbonates, Sverdrup Basin, Canadian Arctic Archipelago. Palaeogeography, Palaeoclimatology, Palaeoecology, 249, 128-159.

Richards, B.C., Barclay, J.E., Bryan, D., Hartling, A., Henderson, C.M., Hinds, R.C., Trollope, F.H., Mossop, G.D., \& Shetsen, I., 1994. Carboniferous strata of the Western Canada Sedimentary Basin, In Mossop, G.D., \& Shetsen, I., (eds) Geologic Atlas of the Western Canada Sedimentary Basin, Geological Survey of Canada, 221-250.

Ross, C.A., 1995. Permian fusulinaceans. In: P.A. Scholle, T.M. Peryt, \& D.S. UlmerScholle (eds.), Permian of Northern Pangea. Vol. 1: Paleogeography, Paleoclimate, Stratigraphy, Springer-Verlag, Berlin, 167-185.

Saxena, S., \& Betzler, C., 2003. Genetic sequence stratigraphy of cool water slope carbonates (Pleistocene Eucla Shelf, southern Australia). International Journal of Earth Sciences, 92, 482-493.

Skinner, J.W. \& Wilde, G.L., 1965. Permian biostratigraphy and fusulinid faunas of the Shasta lake area, Northern California. University of Kansas Paleontological Contributions, Paper Article 6, p. 1-98.

Soreghan, G.S., Soreghan, M.J., \& Hamilton, M.A., 2008. Origin and significance of loess in late Paleozoic western Pangaea; a record of tropical cold? Palaeogeography, Palaeoclimatology, Palaeoecology, 268, 234-259.

Stevens, C.H., Wagner, D.B., \& Sumsion, S.R., 1979. Permian Fusulinid Biostratigraphy, Central Cordilleran Miogeosyncline. Journal of Paleontology, 53 (1), 29-36.

Sun, D., Bloemendal, J., Rea, D.K., Vandenberghe, J., Jiang, F., An, Z., \& Su, R., 2002. Grain-size distribution function of polymodal sediments in hydraulic and aeolian environments, and numerical partitioning of the sedimentary components. Sedimentary Geology, 152, 263-277.

Tabor, N.J., Montanez, I.P., Scotese, C.R., Poulsen, C.J., \& Mack, G.H., 2008. Paleosol archives of environmental and climatic history in paleotropical western Pangea during the latest Pennsylvanian through Early Permian. Special Paper, Geological Society of America, 441, 291-303. 
Vai, G.B., 2003. Development of the palaeogeography of Pangaea from Late Carboniferous to Early Permian. Palaeogeography, Palaeoclimatology, Palaeoecology, 196, 125-155.

Wahlman, G.P., 2002. Upper Carboniferous-Lower Permian (Bashkirian-Kungurian) mounds and reefs. Special Publication, Society for Sedimentary Geology, 72, 271338.

Walsh, J.J., Whitledge, T.E., Kelley, J.C., Huntsman, S.A., \& Pillsbury, R.D., 1977. Further Transition States of the Baja California Upwelling Ecosystem. Limnology and Oceanography, 22, 264-280.

Wamsteeker, M.L., 2007. Diagenetic and geochemical characterization of the Ksituan Member of the Belloy Formation, east central British Columbia Foothills. Bachelors thesis, University of Calgary.

Wang, D., 1993. Conodont biostratigraphy of the Carbon Ridge Formation, Secret Canyon, Fish Creek Range, Nevada. Idaho State University, Pocatello, ID, Boise, 59.

Wanless, H.R., \& Shepard, F.P., 1936. Sea level and climatic changes related to late Paleozoic cycles. Geological Society of America Bulletin, 47, 1177-1206.

Watkins, R., \& Wilson, E.C., 1989. Paleoecologic and biogeographic significance of the biostromal organism Palaeoaplysina in the Lower Permian McCloud Limestone, eastern Klamath Mountains, California. Palaios, 4, 181-192.

Wells, J.W., 1963. Coral Growth and Geochronometry. Nature, 197, 948-950.

Wray, J.L., 1977. Calcareous Algae. Elsevier Scientific Publishing Company, Amsterdam, 185.

Zubin-Stathopoulos, K.D. 2011. Tectonic Evolution, Paleogeography and Paleoclimate of Pennsylvanian-Permian Strata in East-Central British Columbia: Implications from Conodont Biostratigraphy and Carbonate Sedimentology. Masters thesis, University of Calgary. 
Figure captions

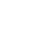

Fig. 1. Study area, east-central British Columbia. The line of cross sections of figures 3 and 8 are also indicated. Modified from Zubin-Stathopoulos et al., 2011.

Fig. 2. Stratigraphy and tectonostratigraphic sequences of east-central British Columbia, Peace River Basin and the 'Banff Region' of the southwestern Alberta Rockies. The focus of this study is highlighted in grey. Colours represent primary lithology.

Blue $=$ limestone, purple $=$ dolostone , orange $=$ chert, yellow $=$ quartz arenite, green=bioturbated/bioclastic sandstone and grey=silty shale. $\mathrm{C}=$ Carboniferous, $\mathrm{P}=$ Permian. Tectonostratigraphic sequences modified from Snyder et al., 2002 and Trexler et al., 2004. Stratigraphy modified from Zubin-Stathopoulos et al., 2011.

Fig. 3. Cross section A-A' as indicated on Figs. 1 and 9. Correlations are based on ages obtained from conodonts, foraminifers and coral.

Fig. 4. (a) Fellers Creek litholog indicating age based on conodont biostratigraphy, formations, conglomerates (red areas) and microfacies (MF) occurrence, modified from Zubin-Stathopoulos et al., 2011. Key to symbols and lithologies is shown in Fig. 5. (b) Conglomerate within the Sakmarian sequence containing reworked Pennsylvanian conodonts; 36.45 m. (c) 2.85 m. Second Belcourt Conglomerate. (d) Basal Belcourt conglomerate; $0 \mathrm{~m}$. 
Fig. 5. (a) Mountain Creek litholog indicating age based on conodont biostratigraphy, formations present and facies occurrence. The upper portion was re-measured at a slightly different location and logged as a separate section; the equivalent level is indicated by a red line. Field occurrences of (b) MF-11 (49.5 m), (c) MF-08 (43.7 m) and (d) MF-10 (41.0 m) are shown.

Fig. 6. Belcourt Formation microfacies (Fellers Creek Facies Assemblage) photomicrographs taken in plain polarized light. All measurements are from the base of the Belcourt Formation (basal conglomerate) at the Fellers Creek section. (a) MF-01, Fellers Creek at 12.35 m (b) MF-01, 11.25 m. (c) MF-02, 18.15 m. (d) MF-03, 40.95 m. (e) MF-04, $27.75 \mathrm{~m}$. (f) Outcrop photograph, knife is $10 \mathrm{~cm}$ long, MF-05, $26.25 \mathrm{~m}$. (g) MF-06, 5.9 m. (H) MF-07, $39.1 \mathrm{~m}$. Ech=echinoderm, Bch=brachiopod, Bry=bryozoan, Fus $=$ Fusulinacean, $\mathrm{Da}=$ Dasycladacean algae, $\mathrm{Paleo}=$ Palaeoaplysina .

Fig. 7. Belcourt Formation microfacies (Mountain Creek Facies Assemblage) photomicrographs taken in plain polarized light. All measurements are from the base of the Mountain Creek section. (a) MF-08, 9 m. (b) MF-08, 104.5 m (c) MF-09, abundant sponge spicules at $107 \mathrm{~m}$ (d) MF-10, $140 \mathrm{~m}$ (e) MF-10, $140 \mathrm{~m}$, from the same thin section indicating possible storm event (f) Outcrop photograph, finger tips for scale, MF11. (g) MF-12, 80.7 m. (h) MF-12, 6.35 m. Ech=echinoderm, Bch=brachiopod, Bry=bryozoan 
46 Fig. 8. Deposition model of time slices roughly based on cross section of Fig. 1 as shown

47 in inset map. FWWB=Fair weather wave base, $\mathrm{SWB}=$ Storm wave base. Facies locations

48 are indicated by facies number. (a) Moscovian profile. The occurrence and distribution of

49 shallow water deposits on the right side of the diagram are based on data from

50 Wamsteeker (2007). K=Extensive supratidal to shallow subtidal dolostone succession

51 (Ksituan Formation) occurs east of the back-ramp setting. (b) Asselian profile showing

52 the Tipinahokan Peninsula and Kisosowin Sea. Known facies are shaded in solid colours

53 (see legend) and interpreted location of facies are slightly transparent. (c) Sakmarian

54 profile. Known facies are shaded in solid colours (see legend) and interpreted location of

55 facies are slightly transparent.

56

Fig. 9. Fusulinaceans from Fellers Creek section. 1, Schubertella sp. Fel_37.5_6c, 0.1mm. 2, Schubertella ex gr. kingi Fel_39.5_1d,0.1mm. 3, Pseudofusulina attenuata Skinner and Wilde Fel_37.5_1a, 1mm.4, Pseudofusulina attenuata Skinner and Wilde Fel_37.5_2b,1mm. 5, Pseudofusulina attenuata Skinner and Wilde Fel_37.5_8a, 1mm. 6, Pseudofusulina attenuata Skinner and Wilde Fel_37.5_1b, 1mm. 7, Pseudofusulina attenuata Skinner and Wilde Fel_39.5_1a, 1mm. 8, Pseudofusulina attenuata Skinner and Wilde Fel_37.5_5a, 1mm.9, Pseudofusulina acuta Skinner and Wilde Fel_37.5_4a, 1mm. 10, Pseudofusulina acuta Skinner and Wilde Fel_37.5_1d,1mm.11, Pseudofusulina acuta Skinner and Wilde, Fel_37.5_5b, $1 \mathrm{~mm}$. 
67 Fig. 10. Asselian-Sakmarian paleogeography and tectonic elements for British Columbia,

68 Alberta and western United States, modified from Henderson et al. (2001). Configuration

69 is based on the contouring function in ArcGIS and the predicted thickness distribution.

70 This is a non-palinspastic reconstruction, so the Kisosowin Sea would be approximately

$7120 \mathrm{~km}$ wider than shown (Richards et al., 1994). The width of the Slide Mountain Ocean

72 and Havallah Basin is speculative. F1 to F3 indicates the location of Fusulinacean

73 assemblages discussed in the text. 


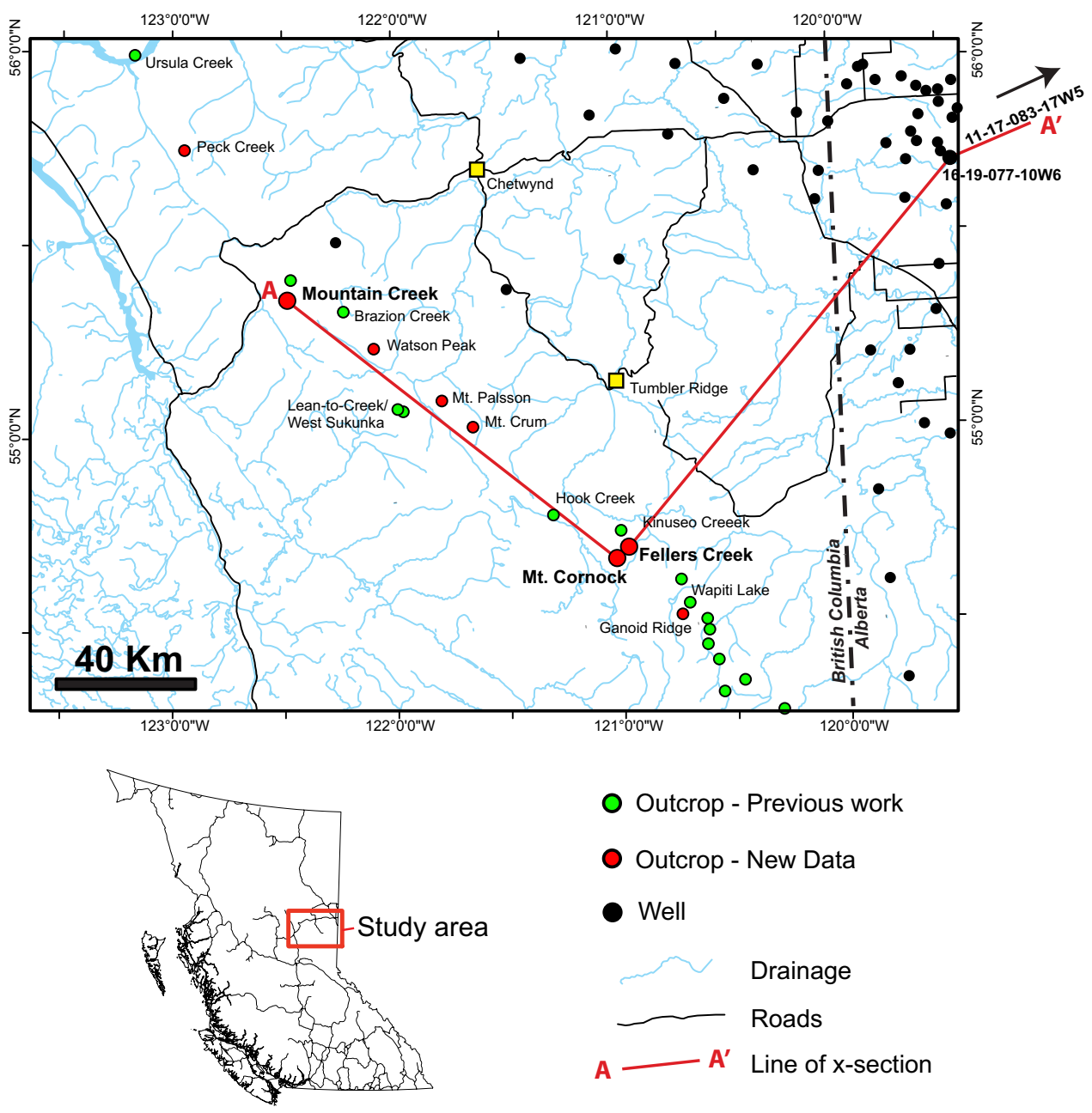




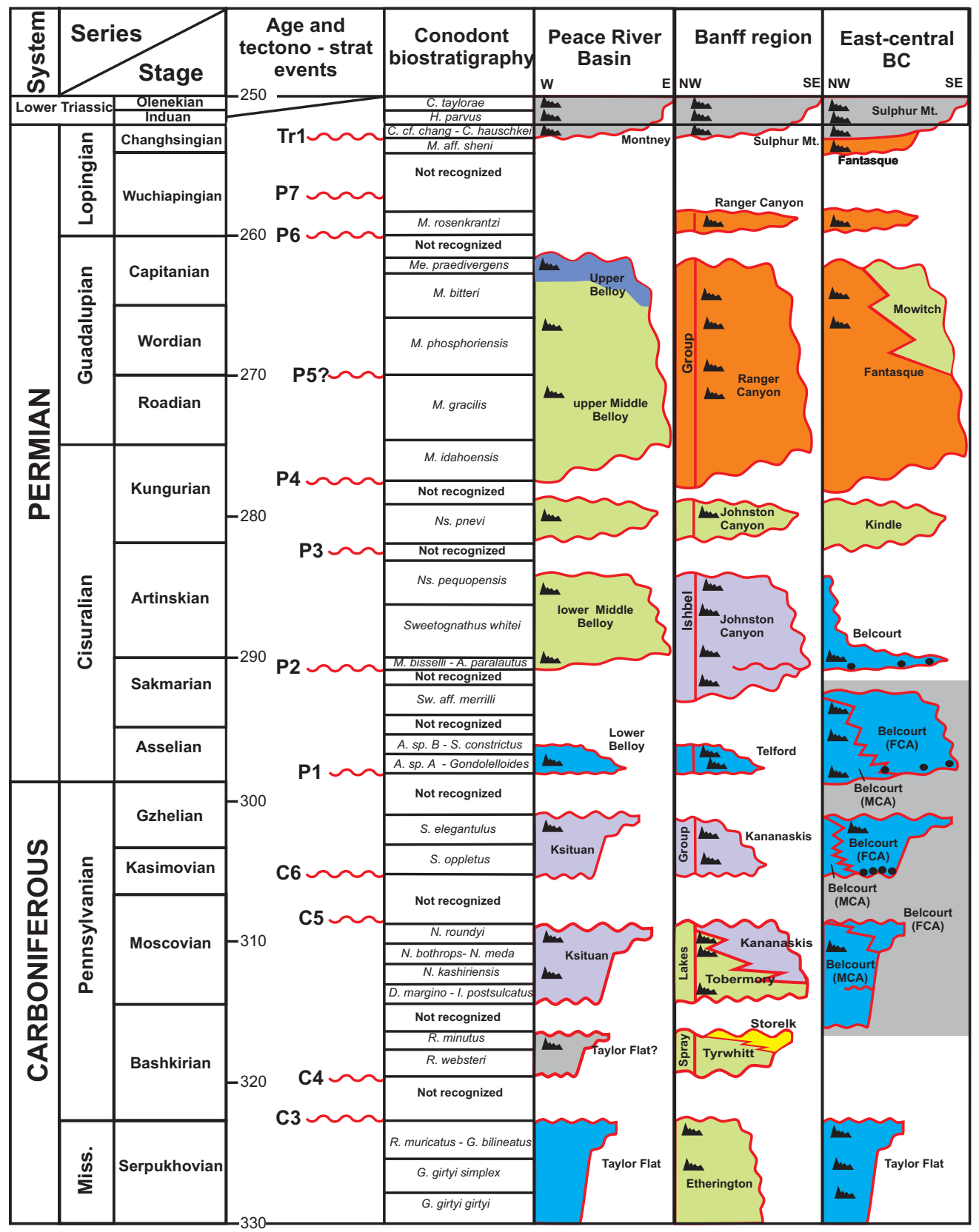




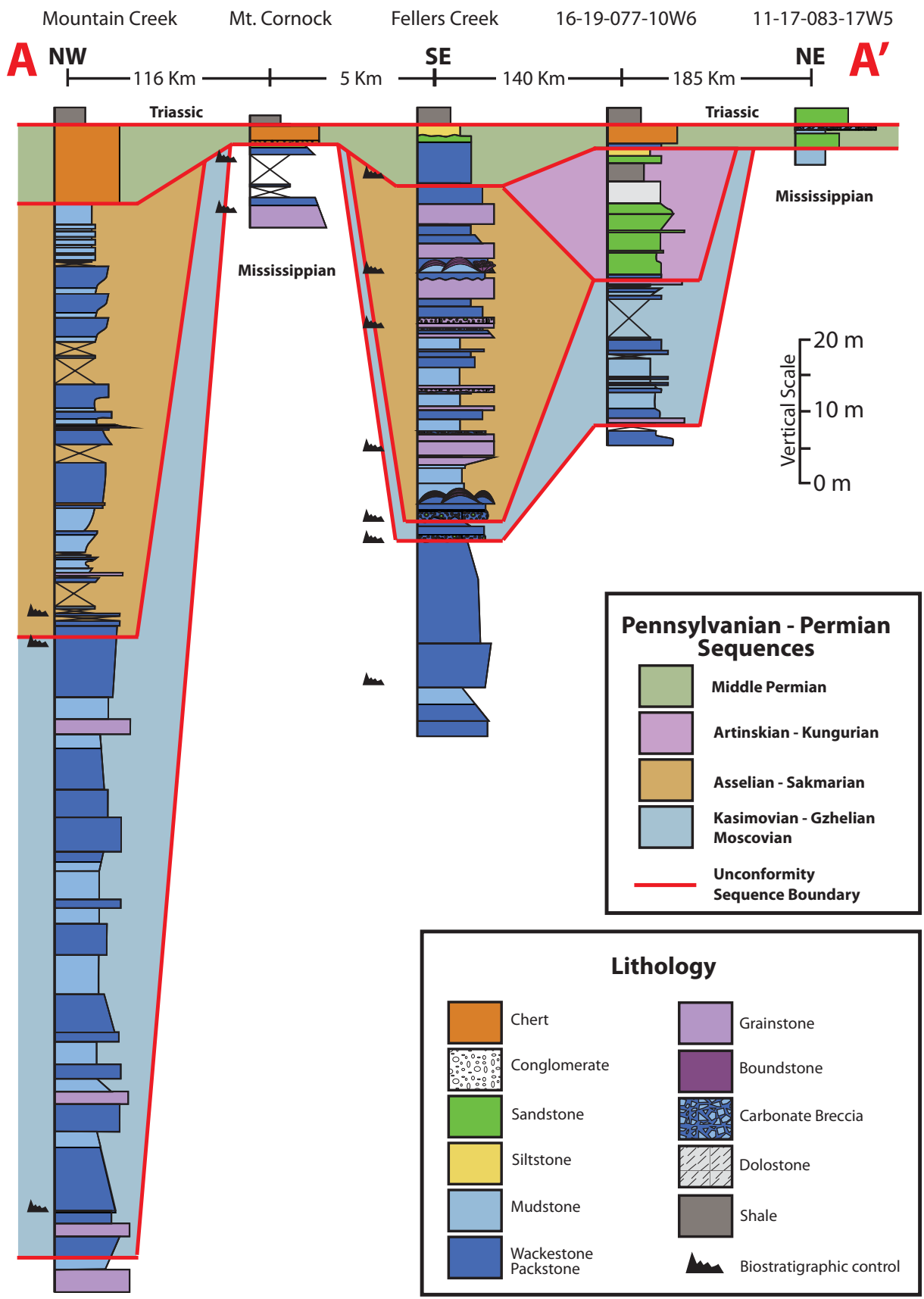



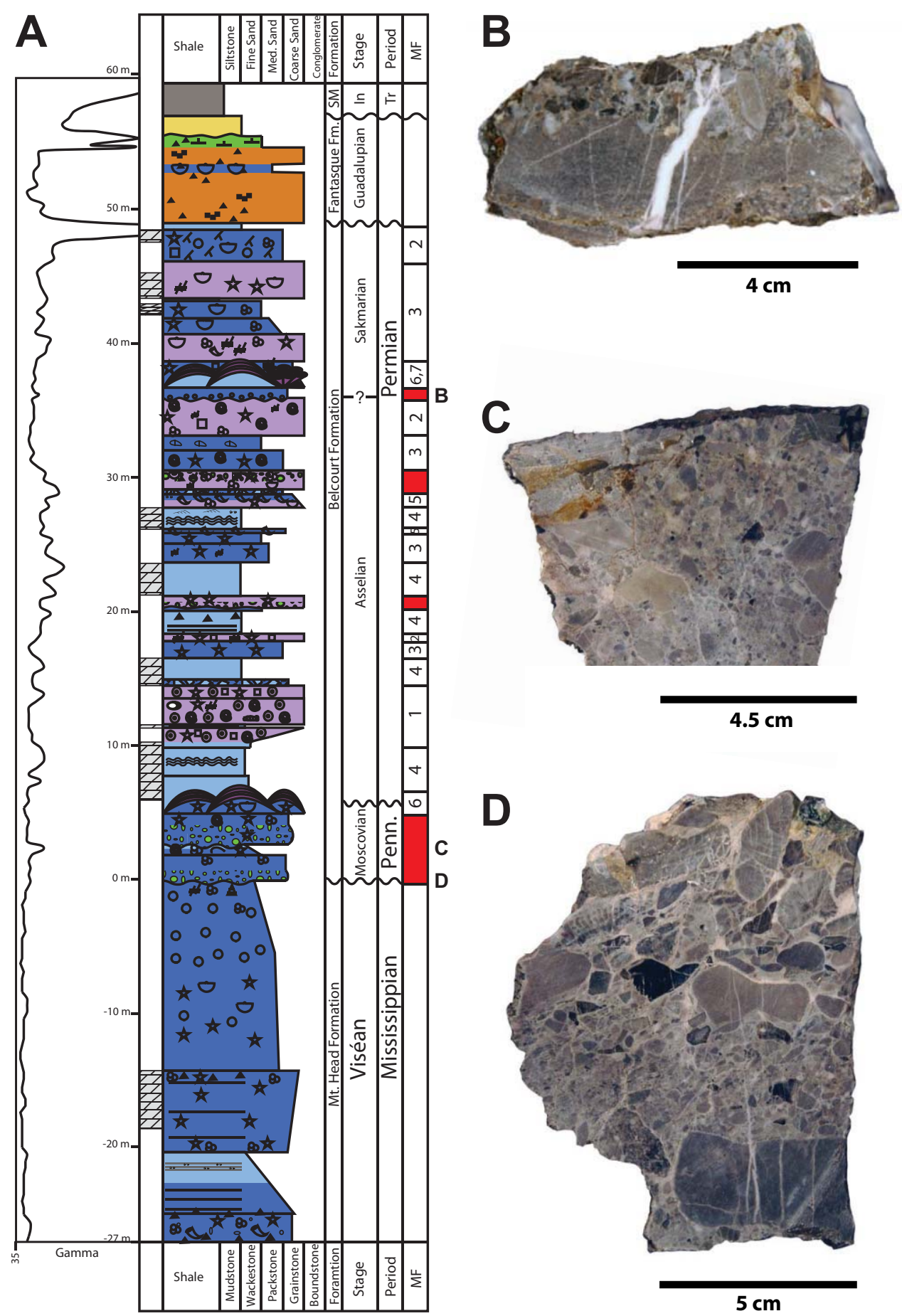


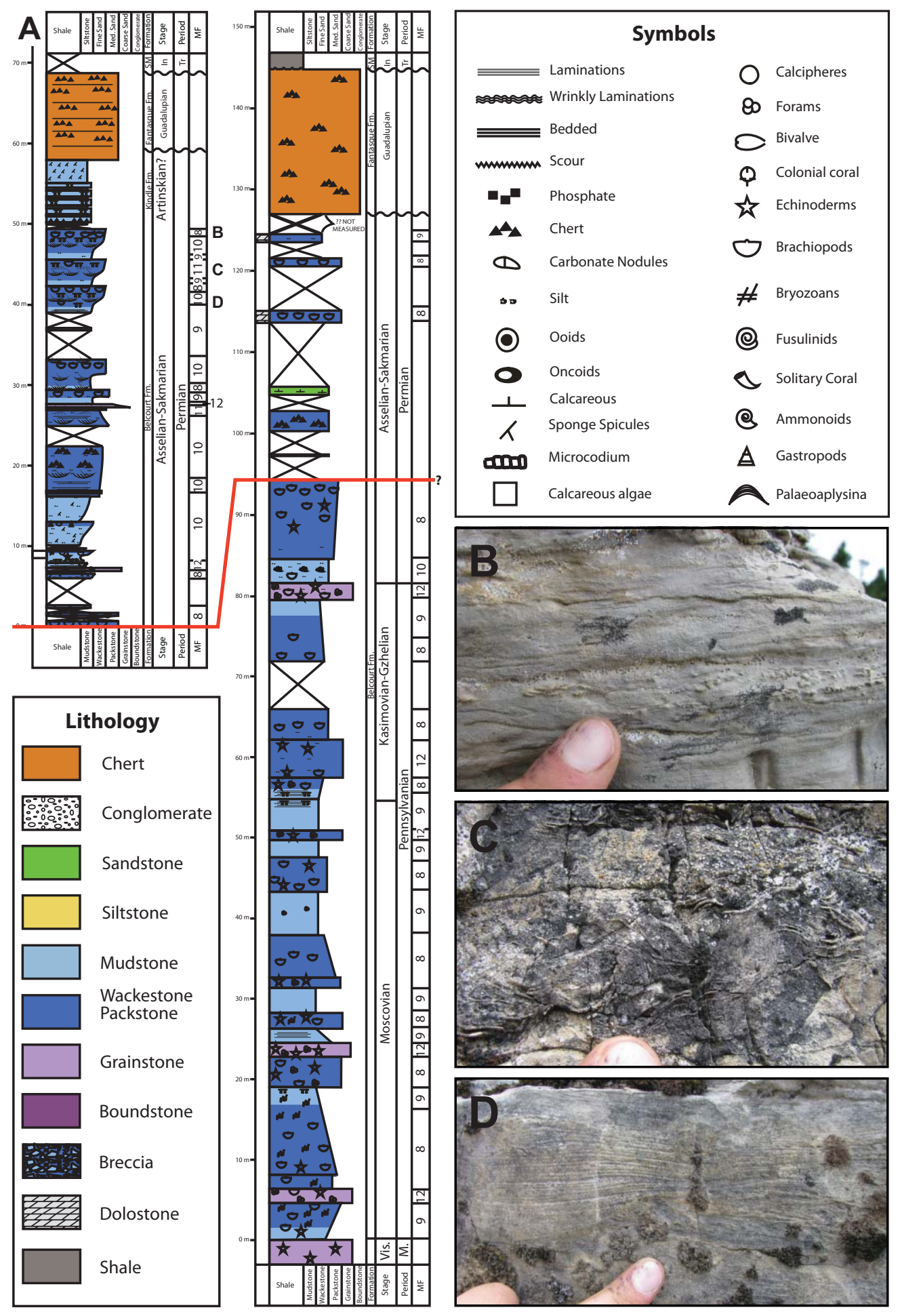



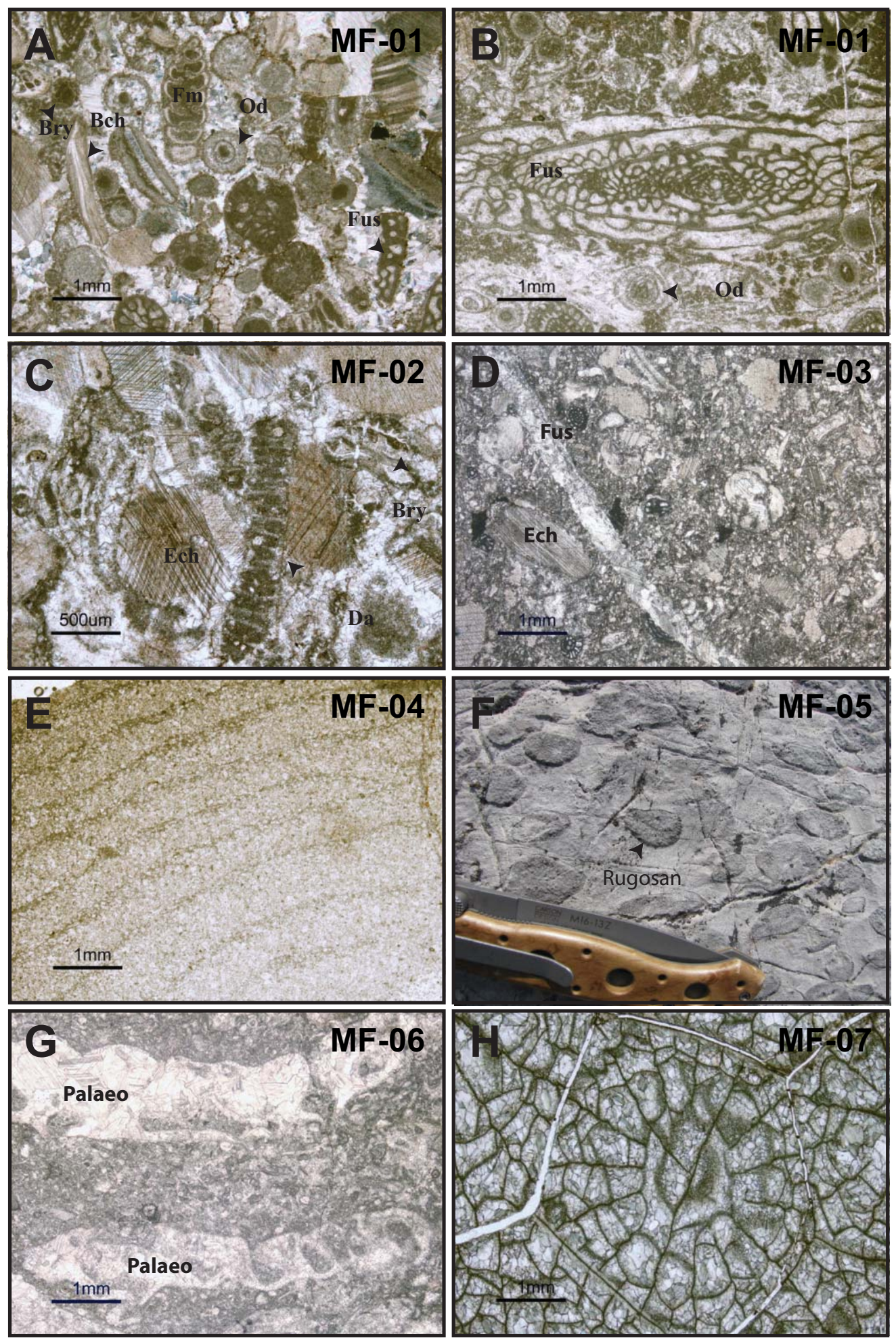

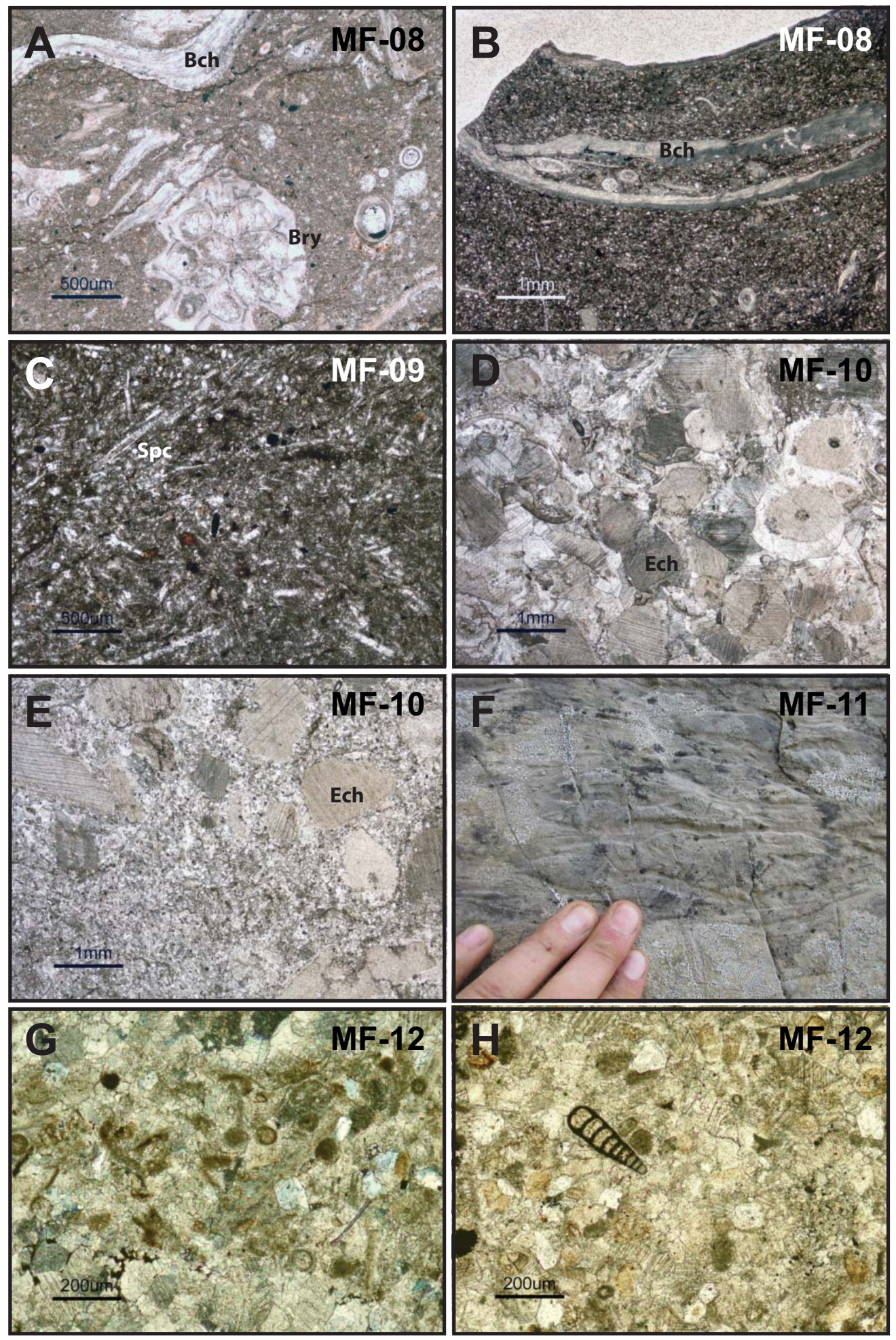


\section{A Moscovian}

\begin{tabular}{|l|l|l|l|l|}
\hline Slope-Basin & Outer Ramp & Back \\
Ramp
\end{tabular}

\section{B Asselian}

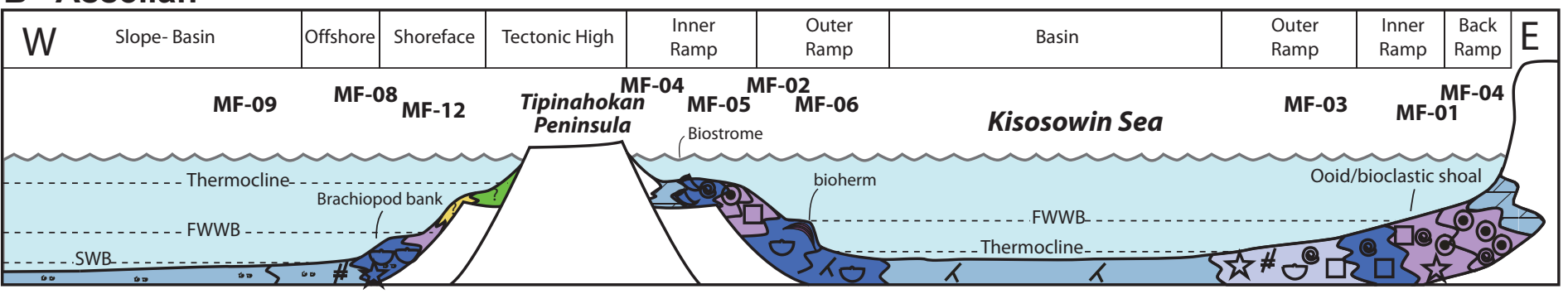

\section{Sakmarian}

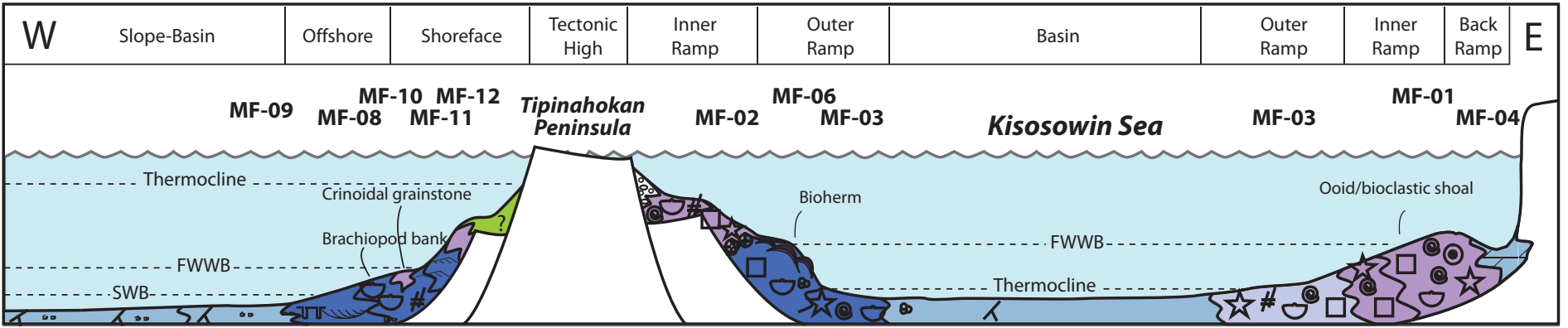
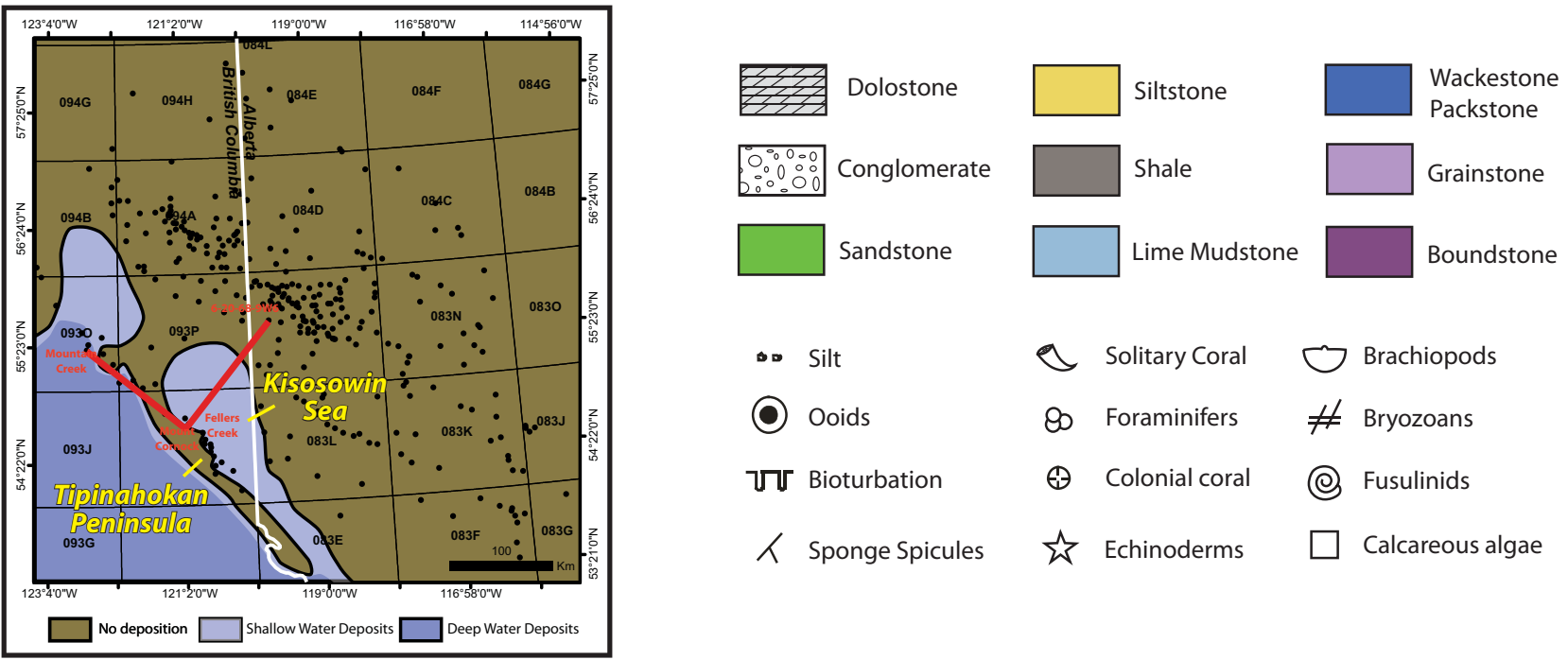
$\therefore$ Silt
$\checkmark$ Solitary Coral
$\circlearrowleft$ Brachiopods
(C) Ooids
80 Foraminifers
\# Bryozoans
凹 Bioturbation
$\Theta$ Colonial coral
(2) Fusulinids
$K$ sponge Spicules
解 Echinoderms
Calcareous algae 

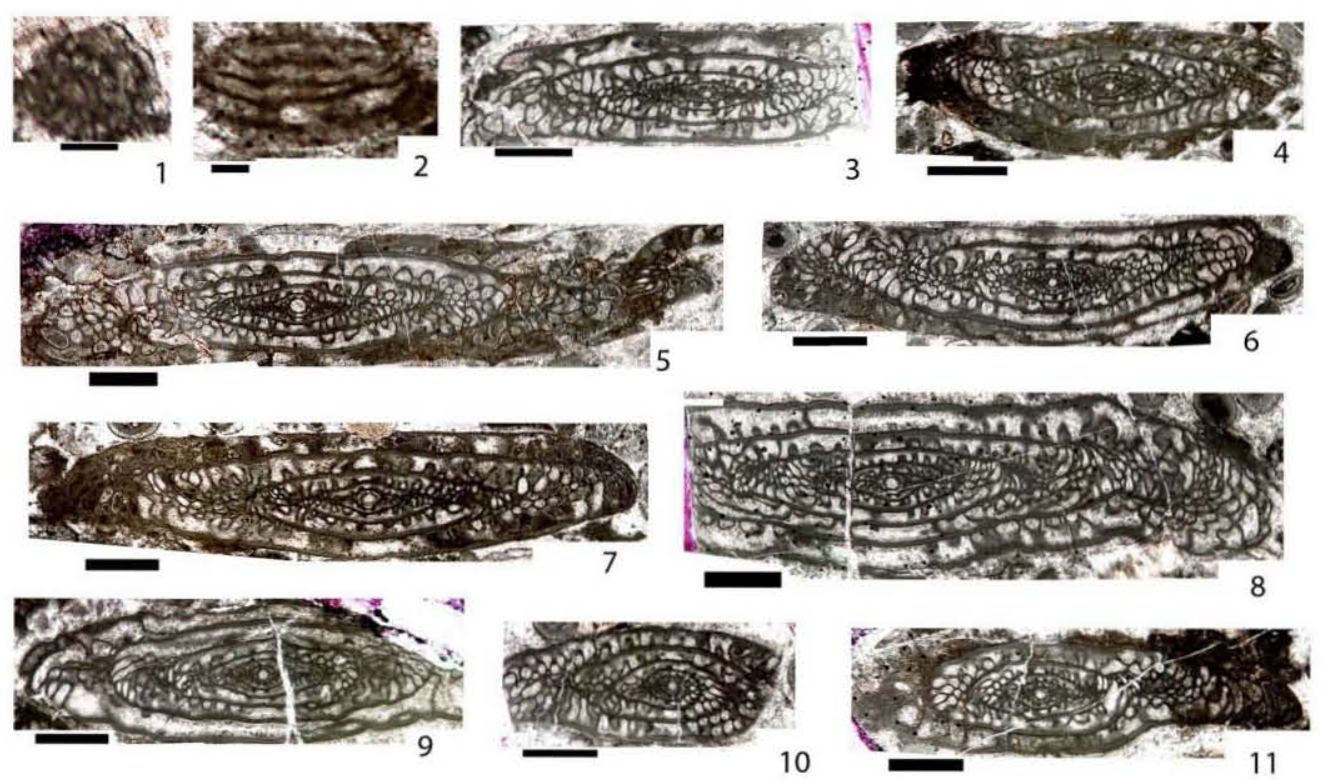


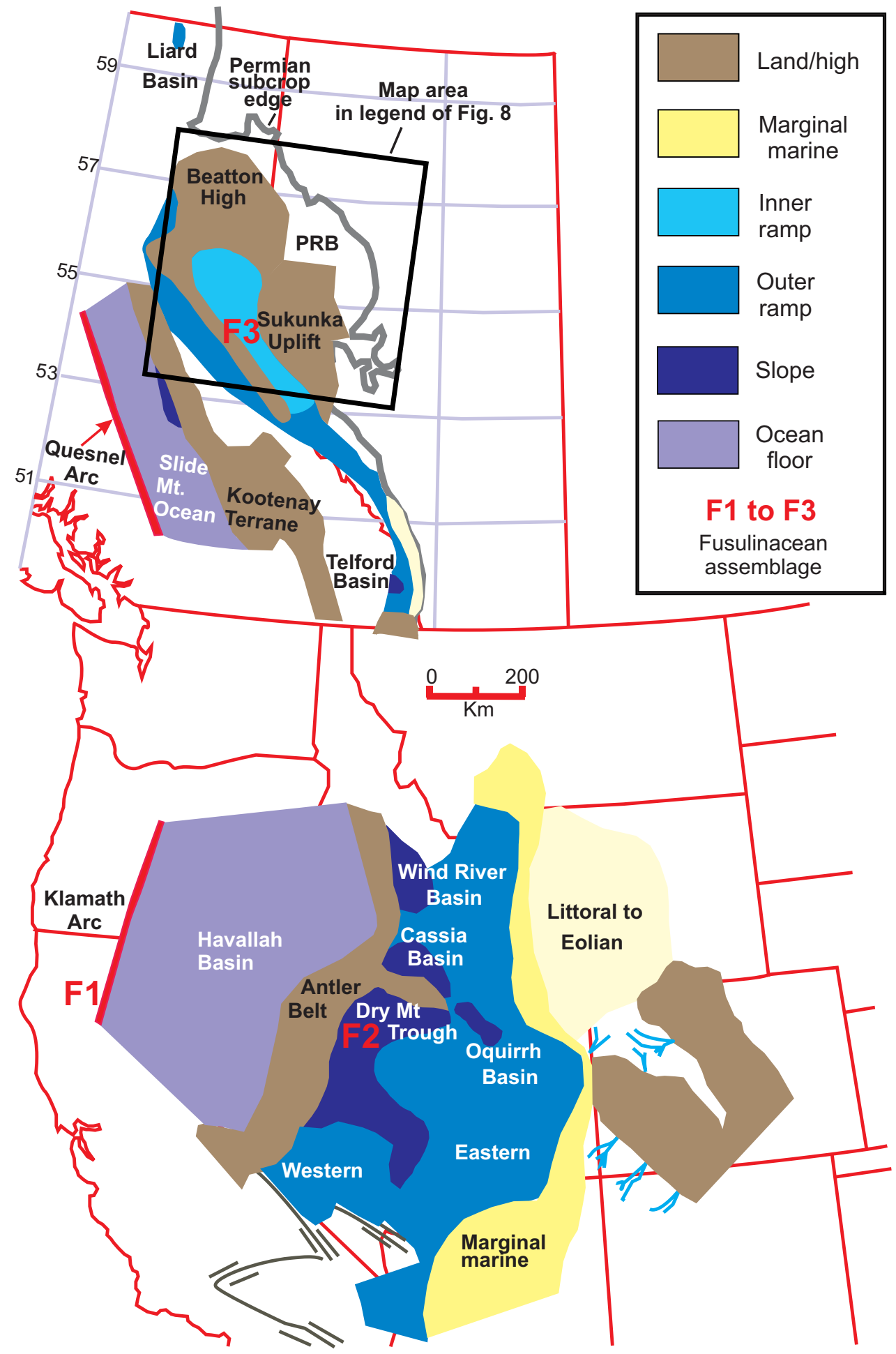


Table 01. Carbonate microfacies of Moscovian to Sakmarian Belcourt Formation, east-central British Columbia, Canada.

FWB=Fairweather Wave Base. SWB=Storm Wave Base. FCA=Fellers Creek facies assemblage. MCA=Mountain Creek facies assemblage. References are: (1) Bamber and Macqueen, 1979, (2) Wamsteeker, 2007 (3) McGugan and Rapson-McGugan, 1976, (4) Kepper, 1966, (5) Mastandrea et al., 2006, (6) Frisia, 1994, (7) Aretz et al., 2010, (8) Coates and Jackson, 1987, (9) Wells, 1963, (10) Mastandrea et al., 2006, (11) Protowentzelella kunthi (pers. comm., E.W. Bamber 2010), (12) Soreghan et al., 2008, (13) Sun et al., 2002, (14) Frey, 1990, (15) Boyd, 2010, (16) Jones, 2010, (17) James et al., 2009, (18) Saxena and Betzler, 2003

\begin{tabular}{|c|c|c|c|c|c|c|}
\hline Name & $\begin{array}{c}\text { ASSOCIATION } \\
\text { Main biota }\end{array}$ & $\begin{array}{c}\text { Figured } \\
\text { elements }\end{array}$ & $\begin{array}{c}\text { Petrographic } \\
\text { attributes }\end{array}$ & $\begin{array}{c}\text { Relevant field } \\
\text { observations }\end{array}$ & Occurrence & Depositional environment \\
\hline $\begin{array}{l}\text { MF-01 } \\
\text { Ooid- } \\
\text { Foraminifer } \\
\text { Grainstone } \\
\text { (Fig. 6A, 6B) }\end{array}$ & $\begin{array}{c}\text { PHOTOZOAN } \\
\text { foraminifera } \\
\text { Fusulinid } \\
\text { Endothyrid } \\
\text { paleotextularid } \\
\text { echinoderm } \\
\text { brachiopod } \\
\end{array}$ & $\begin{array}{l}\text { ooids } \\
(60-90 \%) \\
\text { bioclasts } \\
(10-40 \%) \\
\text { broken fossils } \\
\text { Microcodium } \\
\end{array}$ & $\begin{array}{l}\text { Tangential ooids } \\
\text { former aragonite } \\
\text { recrystalization }\end{array}$ & & $\begin{array}{l}\text { east \& south outcrops (FCA) } \\
\text { Fellers Creek } \\
\text { Kinuseo Creek } \\
\text { Meosin Mountain } \\
\text { Mount Hannington } \\
\text { well c-52-K/93-O- } 8\left({ }^{1}\right) \\
\text { surface-subsurface NE BC }\left({ }^{2}\right)\end{array}$ & $\begin{array}{l}\text { INNER RAMP (SHOAL) } \\
\text { proximity to shoreline } \\
\text { warm } \\
\text { shallow } \\
\text { high energy (FWB) oligotrophic } \\
\text { subaerial exposure }\end{array}$ \\
\hline $\begin{array}{l}\text { MF-02 } \\
\text { Algal-Bioclastic } \\
\text { Grainstone } \\
\text { (Fig. 6C) }\end{array}$ & $\begin{array}{l}\text { PHOTOZOAN } \\
\text { Calcareous alga } \\
\text { Dasycladacean } \\
\text { phylloid } \\
\text { foraminifera } \\
\text { echinoderm } \\
\text { brachiopod } \\
\text { bryozoan } \\
\end{array}$ & $\begin{array}{l}\text { broken fossils } \\
(30-70 \%) \\
\text { bioclasts } \\
(30-70 \%)\end{array}$ & Little to no mud & & $\begin{array}{l}\text { east \& south outcrops (FCA) } \\
\text { Fellers Creek } \\
\text { Kinuseo Creek } \\
\text { Meosin Mountain } \\
\text { Mount Hanington }\left({ }^{1}\right)\end{array}$ & $\begin{array}{l}\text { INNER RAMP } \\
\text { proximity to shoal } \\
\text { warm } \\
\text { shallow } \\
\text { high energy (>FWB) oligotrophic }\end{array}$ \\
\hline $\begin{array}{l}\text { MF-03 } \\
\text { Bryozoan- } \\
\text { Echinoderm } \\
\text { Packstone- } \\
\text { Grainstone } \\
\text { (Fig. 6D) }\end{array}$ & $\begin{array}{l}\text { HETEROZOAN- } \\
\text { EXTENDED } \\
\text { Bryonoderm-ext. } \\
\text { foraminifera } \\
\text { Fusulinid } \\
\text { paleotextularid } \\
\text { rugose coral } \\
\text { solitary } \\
\text { echinoderm } \\
\text { brachiopod } \\
\text { bryozoan } \\
\text { trepostome } \\
\text { fenestrate }\end{array}$ & $\begin{array}{l}\text { bioclasts } \\
(0-30 \%) \\
\text { fossils } \\
\text { whole \& broken } \\
(0-100 \%)\end{array}$ & $\begin{array}{l}\text { Bryozoans branches } \\
\text { intact } \\
<1 \mathrm{~cm} \text { in diameter }\end{array}$ & & $\begin{array}{l}\text { east \& south outcrops (FCA) } \\
\text { Fellers Creek } \\
\text { Kinuseo Creek }\left({ }^{1,3}\right) \\
\text { Meosin Mountain }\left({ }^{1,3}\right) \\
\text { Mount Hanington }\left({ }^{1,3}\right)\end{array}$ & $\begin{array}{l}\text { INNER TO MIDDLE RAMP } \\
\text { cool } \\
\text { shallow } \\
\text { moderate to high energy }(<\mathrm{FWB}) \\
\text { oligotrophic }\end{array}$ \\
\hline $\begin{array}{l}\text { MF-04 } \\
\text { Microbial } \\
\text { Lime- to } \\
\text { Dolomudstone } \\
\text { (Fig. 6E) }\end{array}$ & & $\begin{array}{l}\text { chert clasts } \\
\text { Rare } \\
1-2 \mathrm{~cm} \\
\text { Sub-angular }\end{array}$ & $\begin{array}{l}\text { Dolomitization } \\
\text { Partial to complete } \\
\text { Uniform } \\
\text { Finely crystalline } \\
5-10 \mu \mathrm{m} \text { rhombs } \\
\text { Laminations } \\
\text { Light \& dark bands } \\
\text { Grade into one } \\
\text { another } \\
\end{array}$ & $\begin{array}{l}\text { Recessive }>0.5 \mathrm{~m} \\
\text { units } \\
\text { Poorly exposed } \\
\text { Laminated }\end{array}$ & $\begin{array}{l}\text { east \& south outcrops (FCA) } \\
\text { Fellers Creek } \\
\text { Kinuseo Creek (?) }\end{array}$ & $\begin{array}{l}\text { INTERTIDAL BACK-RAMP } \\
\text { low energy } \\
\text { suspension settling } \\
\text { high energy events } \\
\text { microbial stabilization }\left(^{4,5}\right) \\
\text { stressed environment } \\
\text { evaporative } \\
\left.\text { arid climate }{ }^{6,7}\right) \\
\text { primary to early diagenetic dolomitization }\end{array}$ \\
\hline
\end{tabular}




\begin{tabular}{|c|c|c|c|c|c|c|}
\hline & & & $\begin{array}{l}\text { Fabric } \\
\text { Patchy } \\
\text { Locally brecciated } \\
\end{array}$ & & & \\
\hline $\begin{array}{l}\text { MF-05 } \\
\text { Rugose Coral } \\
\text { Wackestone } \\
\text { Packstone } \\
\text { (Fig. 6F) }\end{array}$ & $\begin{array}{l}\text { PHOTOZOAN(?) } \\
\text { rugose coral } \\
\text { colonial } \\
\text { solitary }\end{array}$ & $\begin{array}{l}\text { whole fossils } \\
(100 \%)\end{array}$ & dark micritic matrix & $\begin{array}{l}30-50 \mathrm{~cm} \text { beds } \\
\text { Rugose corals } \\
\text { distribution not } \\
\text { uniform along } \\
\text { bedding plane } \\
\text { not in life position } \\
\text { not broken or } \\
\text { abraded } \\
\text { corallite diameter: } \\
1-3 \mathrm{~cm} \\
\end{array}$ & $\begin{array}{l}\text { east \& south outcrops (FCA) } \\
\text { Fellers Creek }\end{array}$ & $\begin{array}{l}\text { INNER RAMP (PROTECTED) } \\
\text { biostromes } \\
\text { protected areas >FWB } \\
\text { rugose corals } \\
\text { knocked over \& buried quickly } \\
\text { photic zone limitation }\left({ }^{8-10}\right) \\
\text { no Zooxanthellae-type symbionts } \\
\text { light and depth dependent because photic } \\
\text { zone food source }\left({ }^{7-9}\right)\end{array}$ \\
\hline $\begin{array}{l}\text { MF-06 } \\
\text { Palaeoaplysina } \\
\text { Packstone } \\
\text { Boundstone } \\
\text { (Fig. 6G) }\end{array}$ & $\begin{array}{l}\text { PHOTOZOAN } \\
\text { Calcareous alga } \\
\text { Tubiphytes } \\
\text { Foraminifera } \\
\text { encrusting } \\
\text { echinoderm } \\
\text { brachiopod } \\
\text { bryozoan }\end{array}$ & $\begin{array}{l}\text { fossils } \\
\text { whole \& broken } \\
(100 \%)\end{array}$ & $\begin{array}{l}\text { heavy } \\
\text { recrystalization } \\
\text { of } \\
\text { Palaeoaplysina } \\
\text { plates } \\
\text { Lime mudstone and } \\
\text { wackestone } \\
\text { matrix fills space } \\
\text { in between } \\
\text { Palaeoaplysina } \\
\text { plates }\end{array}$ & $\begin{array}{l}\text { massively bedded } \\
\text { units } \\
\text { beds are } 0.2-1 \mathrm{~m} \\
\text { thick } \\
\text { irregular upper and } \\
\text { lower contacts } \\
\text { Palaeoaplysina } \\
\text { plates are } 2-5 \mathrm{~mm} \\
\text { thick and } 2-5 \mathrm{~cm} \\
\text { long } \\
\text { Plates parallel to } \\
\text { bedding }\end{array}$ & $\begin{array}{l}\text { east \& south outcrops (FCA) } \\
\text { Fellers Creek (two levels) } \\
\text { Kinuseo Creek }\left({ }^{1}\right) \\
\\
\text { western outcrops (MCA) } \\
\text { West Sukunka }\left({ }^{1}\right)\end{array}$ & $\begin{array}{l}\text { OUTER RAMP } \\
\text { bioherms } \\
\quad \text { moderate to low energy } \\
\text { Aassociated with colonial rugose coral } \\
\text { bioherms and grainstone (MF-07 and MF- } \\
\text { 03) that formed within high-energy } \\
\text { environments }\end{array}$ \\
\hline $\begin{array}{l}\text { MF-07 } \\
\text { Colonial } \\
\text { Rugose } \\
\text { Boundstone } \\
\text { (Fig. 6H) }\end{array}$ & $\begin{array}{l}\text { PHOTOZOAN } \\
\text { rugose coral } \\
\text { colonial }\left({ }^{11}\right)\end{array}$ & $\begin{array}{l}\text { fossils } \\
\text { whole } \\
(100 \%)\end{array}$ & & $\begin{array}{l}\text { Irregular patches on } \\
\text { top of and in } \\
\text { sharp contact } \\
\text { with } \\
\text { Palaeoaplysina } \\
\text { Boundstone } \\
\text { Coralites approx. } 1 \\
\text { cm in diameter } \\
\text { Ceroid growth form }\end{array}$ & $\begin{array}{l}\text { east \& south outcrops (FCA) } \\
\text { Fellers Creek (one level) }\end{array}$ & $\begin{array}{l}\text { INNER RAMP } \\
\text { isolated bioherms } \\
\text { high-energy environment } \\
\quad \text { constant wave agitation } \\
\text { photic zone } \\
\text { hard (lithified) substrate }\end{array}$ \\
\hline $\begin{array}{l}\text { MF-08 } \\
\text { Bryozoan- } \\
\text { Brachiopod } \\
\text { Wackestone } \\
\text { Packstone } \\
\text { (Fig. 7A, 7B) }\end{array}$ & $\begin{array}{l}\text { HETEROZOAN } \\
\text { Bryonoderm } \\
\text { echinoderm } \\
\text { brachiopod } \\
\text { bryozoan } \\
\text { trepostome } \\
\text { fenestrate } \\
\text { foraminifera } \\
\text { endothyrid } \\
\text { paleotextularid } \\
\end{array}$ & $\begin{array}{l}\text { fossils } \\
\text { broken } \\
(100 \%)\end{array}$ & $\begin{array}{l}\text { matrix } \\
\text { mixed argillaceous - } \\
\text { lime mud sometimes } \\
\text { dolomitic }\end{array}$ & $\begin{array}{l}\text { Broken fossils } \\
\text { preserved in } \\
\text { multiple different } \\
\text { orientations }\end{array}$ & $\begin{array}{l}\text { western outcrops (MCA) } \\
\text { Mountain Creek } \\
\left.\text { West Sukunka }{ }^{1}\right)\end{array}$ & $\begin{array}{l}\text { MIDDLE RAMP } \\
\text { Relatively shallow } \\
\text { Just below FWB } \\
\text { Low energy (most of the time) } \\
\text { Cool water }\end{array}$ \\
\hline $\begin{array}{l}\text { MF-09 } \\
\text { Bioturbated } \\
\text { Silty Lime } \\
\text { Mudstone } \\
\text { (Fig. 7C) }\end{array}$ & $\begin{array}{l}\text { HETEROZOAN } \\
\text { Bryonoderm } \\
\text { sponge spicule } \\
\text { brachiopod } \\
\text { bryozoan } \\
\text { foraminifera } \\
\text { protonodosarid }\end{array}$ & $\begin{array}{l}\text { fossils } \\
\quad \text { whole \& broken } \\
(100 \%)\end{array}$ & $\begin{array}{l}\text { Terrigenous } \\
\text { component is } \\
\text { sub-angular } \\
\text { coarse, quartz silt } \\
\text { up to } 20 \% \text {. } \\
\text { Sponge spicules } \\
\text { commonly found } \\
\text { in burrow fills. }\end{array}$ & $\begin{array}{l}\text { Variably } \\
\text { bioturbated } \\
\text { feeding and } \\
\text { dwelling traces } \\
\quad \text { Chondrites } \\
\quad \text { Helminthopsis } \\
\text { Palaeophycus } \\
\text { Planar laminae } \\
\end{array}$ & $\begin{array}{l}\text { western outcrops (MCA) } \\
\text { Mountain Creek } \\
\text { West Sukunka }\left(^{1}\right)\end{array}$ & $\begin{array}{l}\text { OUTER RAMP } \\
\text { Relatively deep } \\
\text { Below FWB and SWB } \\
\text { Low energy } \\
\text { Sporadic high-energy events } \\
\text { Suspension settling } \\
\text { Aeolian silt in arid climate }\left({ }^{12-13}\right) \\
\text { Oxic sea floor conditions } \\
\text { Cool to cold water } \\
\end{array}$ \\
\hline
\end{tabular}




\begin{tabular}{|c|c|c|c|c|c|c|}
\hline & & & & $\begin{array}{l}\text { often disrupted by } \\
\text { bioturbation }\end{array}$ & & \\
\hline $\begin{array}{c}\text { MF-10 } \\
\text { Hummocky } \\
\text { Cross-Stratified } \\
\text { Silty Packstone } \\
\text { Grainstone } \\
\text { (Fig. 7D, 7E) }\end{array}$ & $\begin{array}{l}\text { HETEROZOAN } \\
\text { Bryonoderm } \\
\text { echinoderm } \\
\text { brachiopod } \\
\text { bryozoan } \\
\text { ostracod }\end{array}$ & $\begin{array}{l}\text { fossils } \\
\text { broken } \\
\text { silt-size } \\
(100 \%)\end{array}$ & $\begin{array}{l}\text { Microgranular } \\
\text { fabric }\end{array}$ & $\begin{array}{l}\text { Small-scale } \\
\text { hummocky } \\
\text { cross-stratified } \\
\text { silty } \\
\text { Crinoidal } \\
\text { packstone/grains } \\
\text { tone single bed } \\
\text { grades upwards } \\
\text { from grainstone } \\
\text { to a packstone } \\
\text { overlain by } \\
\text { Zoophycos(?)- } \\
\text { rich beds }\end{array}$ & $\begin{array}{l}\text { western outcrops (MCA) } \\
\text { Mountain Creek } \\
\text { West Sukunka(?) }\left(^{1}\right)\end{array}$ & $\begin{array}{l}\text { SHOREFACE TO OFFSHORE } \\
\text { TRANSITION } \\
\text { Relatively shallow water } \\
\text { below FWB, above SWB } \\
\text { Regular storms } \\
\text { Storm-related lag deposition } \\
\text { Cool water } \\
\text { Opportunistic organisms }\left({ }^{14}\right)\end{array}$ \\
\hline $\begin{array}{l}\text { MF-11 } \\
\text { Silty Cross- } \\
\text { Bedded } \\
\text { Packstone } \\
\text { Grainstone } \\
\text { (Fig. 7F) } \\
\end{array}$ & $\begin{array}{l}\text { HETEROZOAN } \\
\text { Bryonoderm } \\
\text { brachiopod } \\
\text { bryozoan }\end{array}$ & $\begin{array}{l}\text { fossils } \\
\text { bioclasts } \\
\text { silt-size } \\
(100 \%)\end{array}$ & $\begin{array}{l}\text { silty (as least } 20 \% \text { ) } \\
\text { and argillaceous } \\
\text { microgranular }\end{array}$ & Ripples & $\begin{array}{l}\text { western outcrops (MCA) } \\
\text { Mountain Creek } \\
\left.\text { West Sukunka(?) }{ }^{1}\right)\end{array}$ & $\begin{array}{l}\text { SHOREFACE } \\
\text { shallow water } \\
\text { above FWB } \\
\text { Cool, eutrophic(?) water }\left({ }^{15,16}\right)\end{array}$ \\
\hline $\begin{array}{c}\text { MF-12 } \\
\text { Bioclastic } \\
\text { Grainstone } \\
\text { Packstone } \\
\text { (Fig. } 7 \mathrm{G}, 7 \mathrm{H} \text { ) }\end{array}$ & $\begin{array}{l}\text { HETEROZOAN } \\
\text { Bryonoderm } \\
\text { echinoderm } \\
\text { brachiopod (rare) } \\
\text { bryozoan (rare) } \\
\text { foraminifera } \\
\text { endothyrid } \\
\text { paleotextularid } \\
\end{array}$ & $\begin{array}{l}\text { fossils } \\
\text { bioclasts } \\
\text { silt-size } \\
\text { (70-100\%) } \\
\text { Broken } \\
(10-30 \%) \\
\text { peloid }\end{array}$ & $\begin{array}{l}\text { Matrix is mixed } \\
\text { argillaceous and } \\
\text { micrite }\end{array}$ & & $\begin{array}{l}\text { western outcrops (MCA) } \\
\text { Mountain Creek (upper part) } \\
\text { West Sukunka(?) }\left({ }^{1}\right)\end{array}$ & $\begin{array}{l}\text { INNER RAMP } \\
\text { Relatively shallow water } \\
>\text { FWB, above SWB } \\
\text { High energy, constant agitation } \\
\text { Periodic storms } \\
\text { Cool water } \\
\text { Sediment-starved environment(?) }\left({ }^{17,18}\right)\end{array}$ \\
\hline
\end{tabular}

